NBER WORKING PAPER SERIES

\title{
SPECIALIZATION AND REGULATION: \\ THE RISE OF PROFESSIONALS AND THE EMERGENCE OF OCCUPATIONAL LICENSING REGULATION
}

\author{
Marc T. Law \\ Sukkoo Kim \\ Working Paper 10467 \\ http://www.nber.org/papers/w10467 \\ NATIONAL BUREAU OF ECONOMIC RESEARCH \\ 1050 Massachusetts Avenue \\ Cambridge, MA 02138 \\ May 2004
}

The views expressed herein are those of the author(s) and not necessarily those of the National Bureau of Economic Research.

(C)2004 by Marc T. Law and Sukkoo Kim. All rights reserved. Short sections of text, not to exceed two paragraphs, may be quoted without explicit permission provided that full credit, including (C notice, is given to the source. 
Specialization and Regulation: The Rise of Professionals and the Emergence of Occupational Licensing Regulation Marc T. Law and Sukkoo Kim

NBER Working Paper No. 10467

May 2004

JEL No. J4, K2, L5, N4

\section{$\underline{\text { ABSTRACT }}$}

This paper explores the origins and effects of occupational licensing regulation in late nineteenth and early twentieth century America. Was licensing regulation introduced to limit competition in the market for professional services at the expense of efficiency? Or was licensing adopted to reduce informational asymmetries about professional quality? To investigate these hypotheses, we analyze the determinants of licensing legislation and the effect of licensing on entry into eleven occupations. We also examine the impact of medical licensing laws on entry into the medical profession, physician earnings, mortality rates, and the incidence of medical malpractice. We believe that, at least for the Progressive Era, the evidence is more consistent with the asymmetric information hypothesis than the industry capture hypothesis.

Marc T. Law

University of Vermont

Department of Economics

Old Mill Building, 94 University Place

Burlington, VT 05405-0114

marc.law@uvm.edu

Sukkoo Kim

Washington University

Department of Economics

One Brookings Drive

St. Louis, MO 63130-4899

and NBER

soks@economics.wustl.edu 
Not long ago, the Governor of a midwestern state was approached by representatives of a particular trade anxious to enlist the Governor's support in securing passage of legislation to license their trade.

"Governor," the men said, "passage of this licensing act will ensure that only qualified people will practice this occupation; it will eliminate charlatans, incompetents or frauds; and it will thereby protect the safety and welfare of the people of this state."

The governor, from long experience, was somewhat skeptical. "Gentlemen," he asked, "are you concerned with advancing the health, safety and welfare of the people under the police powers of the state, or are you primarily interested in creating a monopoly situation to eliminate competition and raise prices?"

The spokesman for the occupational group smiled and said, "Governor, we're interested in a little of each." (Council of State Governments, 1952, p. 1)

\section{Introduction}

The late nineteenth and the early twentieth centuries witnessed the birth of modern day professions. Prior to the late 1800 s, only medicine, law and theology were considered "learned professions" (Friedman and Kuznets 1945). The growth of modern day professions was fueled not only by a transformation of these older professions but also by a significant increase in new professional occupations such as teachers, engineers, dentists, and accountants to list a few. In 1900, a little over 4 percent of the labor force was engaged in professional and technical occupations; that figure rose steadily to about 20 percent in 2000 (US Department of Commerce 2001).

Professionals differ from ordinary laborers in a variety of ways. Compared to other types of workers, professionals acquire more advanced levels of training and education, earn higher wages, and generally possess greater status in society. In addition, unlike most occupations, entry into and standards of practice within professional occupations are regulated by professional societies and by government. Most often, professions are self-regulated. Professional societies regulate their own practice by determining standards of entry and by developing a code of ethics. Local and state governments often delegate the regulatory powers of professional licensing to representatives of the professions themselves.

For many economists, the regulation of entry by professional societies and local and state governments is primarily motivated by a profession's interest in "creating a monopoly situation to limit competition and raise prices." Ever since the classic study by Friedman and Kuznets (1945), economists have generally believed that the wages of 
physicians and other professionals are often artificially raised by regulation. The dominant view today is that the regulatory process has been captured by industry to erect entry restrictions for its own benefit (Stigler 1971). Indeed, most scholars who have analyzed the effects of occupational licensing regulation argue that the evidence supports of some version of the capture theory (Friedman 1962; Moore 1964; Holen 1965; Benham, Maurizi and Reder 1968; Kessel 1970, 1972; Maurizi 1974; Benham and Benham 1975; Leffler 1978; Pashigian 1979; White 1980; Fraundorf 1984; Burnstein and Cromwell 1985; Noerther 1986; Svorney 1987; Graddy 1991).

However, there is an alternative explanation. The sale and purchase of professional services are often subject to problems of asymmetric information. ${ }^{1}$ More often than not, sellers of specialized services are better informed than buyers about the various dimensions of product quality. When informational asymmetries are significant, then the classic "lemons" problem may arise as lower quality goods drive out higher quality goods from the market (Akerlof 1970). Thus, professionals may choose to selfregulate, or professionals and consumers may seek government regulation to "eliminate charlatans, incompetents or frauds" and "protect the safety and welfare" of consumers (Arrow 1963; Leland 1979; Weingast 1980). In this instance, regulation may increase the wages of professionals, not because it limits competition at the expense of efficiency, but because it improves the quality of services that consumers expect to receive.

Yet despite the existence of a plausible alternative explanation for why professions are regulated, most scholars have not taken this thesis very seriously. We know of no empirical study of professional licensing regulation that is based on

\footnotetext{
${ }^{1}$ While there are numerous definitions of the term "professions," most definitions seem to suggest that professions sell specialized services whose product quality is difficult to verify ex ante by the buyer. According to the Merriam-Webster Dictionary (1997, p. 585) a profession is "a calling requiring specialized knowledge and often long academic training." Taking this definition a step further, William Rothstein (1972, p. 8) argues that a profession is "a manner of earning a livelihood through the application of a body of highly abstract knowledge in some set of institutions." An even more detailed definition of the word "profession" has been offered by Paul Starr, who writes (1982, p. 15): "A profession... is an occupation that regulates itself through systematic, required training and collegial discipline; that has a base in technical, specialized knowledge; and that has a service rather than a profit orientation enshrined in its code of ethics." It is also interesting to note that the U.S. judges ultimately classified medical malpractice suits as torts rather than contracts. Judges ruled that a "meeting of minds" was not possible between a physician and a patient. Contracts between physicians and patients were not possible because the latter lacked the necessary knowledge to bargain equally. However, physicians could be sued under torts defined broadly as "private civil wrongs that violate certain duties or responsibilities." See Kenneth De Ville (1990).
} 
informational asymmetries. In many respects, this is not surprising: in practice, it is very difficult to develop empirical tests that clearly distinguish the two hypotheses for professional regulation. In fact, most empirical evidence presented in favor of the capture hypothesis is observationally equivalent with the asymmetric information hypothesis.

Studies typically find that licensing is correlated negatively with entry and positively with earnings. Additionally, studies also find that the occupational group being licensed is an important constituency in favor of regulation. However, scholars often fail to note that these correlations are predicted by both theories of professional regulation.

The two theories do have some sharp predictive differences. If government regulation is adopted to solve problems of asymmetric information, then licensing should improve the quality of services. On the other hand, if licensing regulation is a result of industry capture, then the quality of services should be unchanged, or may even deteriorate as competition is reduced. Unfortunately, it is extremely difficult to obtain information on the quality of services provided by professionals. ${ }^{2}$ Unlike the output of manufacturing, the output of services is difficult to measure and quantify. ${ }^{3}$ Wages are often used as a measure of value added for services. However, for professional services, wages may be a poor measure of value added since, as we noted earlier, they can be artificially inflated through regulation.

We explore in this paper the causes and consequences of state government occupational licensing regulation in the United States during the Progressive Era. This period witnessed not only a sharp increase in professionals in numerous occupations, but also a surge in state licensing legislation for professions and trades. By the mid-twentieth century, there were more than 1,200 state occupational licensing statutes, averaging 25 per state, for at least 75 occupations ranging from physicians to embalmers. Typically, licensing boards were created to control entry into an occupation and to enforce standards of practice among licensed practitioners. However, the form and content of licensing

\footnotetext{
${ }^{2}$ A handful of scholars have examined the relationship between licensing and proxies for professional quality using contemporary data. See Caroll and Gaston (1981), Feldman and Begun (1985) and HaasWilson (1986).

${ }^{3}$ The problems of measuring the output of services are addressed in Fuchs (1969).
} 
legislation differed greatly across occupations, states and time. In many occupations, the qualifications for licensure were raised and tightened over the years. ${ }^{4}$

We examine state licensing regulations of eleven occupations between 1880 and 1930. ${ }^{5}$ For these occupations, we study the various factors that led to the adoption of licensing regulation, and whether the introduction of licensing restricted entry into these occupations. When we estimate a discrete time hazard model of the adoption of licensing for the pooled data on eleven occupations, we find that urbanization was a major factor in the enactment of licensing regulation, as was the size of the occupational group. When the model is estimated for specific occupations, the urbanization rate is significant for architects, attorneys, physicians and veterinarians. For barbers, beauticians, dentists, engineers, nurses, physicians, plumbers and veterinarians, a greater representation of their workforce in a given state increased the probability of adopting licensing legislation. However, when we estimate the impact of licensing legislation on entry, we find that licensing legislation did not restrict entry into most occupations. Licensing regulations appear to have restricted entry into only four professions: architects, dentists, physicians and veterinarians. In general, except for these four occupations, it appears that licensing requirements were either too weak or licensing boards too ineffective to limit entry into most occupations in our sample.

At least for the Progressive Era, we believe that the overall evidence on licensing gathered in this paper is more consistent with the asymmetric information hypothesis than the industry capture story. In this period, information asymmetries for consumers increased markedly as society became more specialized and urbanized. As growth in scientific knowledge was accompanied by specialization, individuals became less knowledgeable about the goods and services they purchased in the marketplace. Moreover, as society became urbanized, market exchanges became more anonymous so that traditional mechanisms for overcoming the asymmetric information problem were less useful. Not surprisingly, licensing regulations were more likely to be adopted in states with significant urban populations.

\footnotetext{
${ }_{5}^{4}$ See Council of State Governments (1952).

${ }^{5}$ Occupations in our sample include architects, attorneys, barbers, beauticians, dentists, engineers, nurses, physicians, plumbers, teachers and veterinarians.
} 
Furthermore, licensing regulations seem to have been stricter for those occupations where informational asymmetries were most troubling to consumers. Consumers are more likely to be concerned with informational asymmetries when they purchase services directly from professionals and when the consequences of poor purchases are great. Consumers are less likely to be concerned with regulating professions such as engineers and nurses because they are mostly hired by firms rather than consumers, and are also less likely to be concerned with regulating professions such as barbers and beauticians because the costs of a bad haircut are relatively low. ${ }^{6} \mathrm{We}$ do not believe that it is merely a coincidence that the entry and standards of practice are most strictly regulated for physicians, dentists, and veterinarians, whose services are purchased directly by consumers and where the costs of receiving poor services could be high and sometimes even catastrophic. ${ }^{7}$

To delve more deeply into whether Progressive Era licensing regulation was introduced to reduce information asymmetries or to limit competition, we analyze the medical profession in greater detail. We collect detailed information on specific licensing regulations to examine what types of regulations were most effective in regulating entry. Since licensing regulations were rarely static, especially for physicians, it is important to determine what types of regulations had the most significant impact on entry. Indeed, we investigate not only how the evolution of licensing standards affected entry, but also whether licensing affected the earnings of physicians and the quality of physicians' services. In particular, we examine whether medical licensing lowered mortality rates and the incidence of medical malpractice suits or whether it merely restricted entry into the medical profession and raised physician incomes.

We find that those licensing regulations that had the most negative impact on entry were also those that were most likely to increase physician quality. A close analysis of the effects of specific state medical licensing requirements on the number of physicians per capita shows that the licensing regulations that most sharply reduced entry were those that increased the length of the medical degree and increased the length of

\footnotetext{
${ }^{6}$ For example, the American Machinist wrote that a code of ethics was unnecessary for engineers as compared to doctors and lawyers since few engineers were independent consultants: "The employer [of the engineer] is the final judge of the manner in which his money shall be spent. He is usually more or less of an engineer himself, and frequently a competent one" (quoted in Calvert 1967, p. 267).
} 
pre-medical college education. ${ }^{8}$ However, unlike Friedman and Kuznets (1945), we do not find that licensing regulation raised physician incomes, either absolutely or relative to dentists. We also find that licensing regulation reduced mortality rates from illnesses where the quality of physicians is likely to have made a difference during this period. While states with stricter licensing regulations did not have lower overall mortality rates or lower mortality rates due to cancer and diabetes, they did have significantly lower rates of infant, maternal and appendicitis mortality.

Not all of the consequences of licensing were in the general interests of practicing physicians. If physicians were unified in their desire for licensing regulation, they were also unified in their opposition to the growth of medical malpractice suits during this period. Surprisingly, we find that licensing increased rather than reduced the incidence of state appellate malpractice suits. It appears that medical licensing regulations, by better defining the standards of local practice, made it easier for consumers to successfully sue physicians for poor outcomes. ${ }^{9}$ Since licensing regulations were unlikely to eliminate all unqualified physicians, malpractice suits may have raised the costs of operation for less skilled physicians. However, because even qualified physicians were threatened by the potential for frivolous lawsuits, physicians did not find it in their collective interests to defend the rights of consumers to sue physicians.

While it is extremely difficult to rule out the importance of the industry capture explanation for professional regulation, we urge scholars to pay greater attention to motivations based on asymmetric information. The desire to eliminate charlatans and quacks from a given profession is more than mere rhetoric for both the practitioner and the consumer. However, we are fully aware that if professionals are granted powers to limit entry into their own professions, then the potential for misusing the state for private

\footnotetext{
${ }^{7}$ Architects are an exception to this explanation.

${ }^{8}$ Friedman and Kuznets (1945) report that acceptance rates at medical schools between 1926 and 1941 were near $60 \%$ where as the passing rate for licensing was around $96 \%$. For dental schools in 1941, the acceptance rate was over $83 \%$ whereas the licensing passing rate was a little over $80 \%$. However, it would be erroneous to believe that medical schools rather than licensing regulation were responsible for restricting entry into medicine. It is more likely that medical schools, as compared to dental schools, internalized licensing restrictions into their admissions decisions and did not accept unqualified applicants in order to preserve their reputations. Most scholars believe that stricter licensing regulation was the binding constraint on the number of physicians admitted to the profession. See, for instance, Starr (1982).

${ }^{9}$ See Smith (1941a-d) and De Ville (1990) for general discussions on the rise of malpractice suits in the United States over the nineteenth century.
} 
gain is always present. Indeed, the fundamental dilemma of licensing regulation is that it can improve efficiency, or limit competition, or do "a little of each."

\section{The Growth of Professions and the Emergence of Occupational Licensing}

Scientific knowledge expanded tremendously during the nineteenth and twentieth centuries. The scope and depth of human understanding about the physical, social, and biological world underwent a massive expansion during these centuries. Not only did the total stock of knowledge grow, but scientific knowledge became increasingly specialized (Price 1963). This expansion of specialized knowledge is illustrated in Tables 1 and 2 which present data on the number of scientific periodicals published in a variety of disciplines from the eighteenth century until the mid-twentieth century. ${ }^{10}$ The data reveal a dramatic increase in the number of scientific periodicals published over time and an increase in the number of field-specific scientific journals.

Over time, this new scientific knowledge found applications in occupations like medicine, dentistry, architecture, and engineering. For instance, advances in chemistry, physics, and geology during the nineteenth century made it possible to develop specialized fields within engineering. Specialized engineering fields like chemical, mechanical, electrical, geological and metallurgical engineering thus gradually came into being. A systematic understanding of increasingly specific scientific disciplines became part of the training of new engineers (Society for the Promotion of Engineering Education 1930). Meanwhile in medicine, the development of basic biological sciences like bacteriology, microbiology, immunology, and biochemistry, made it possible for physicians to identify the sources of particular diseases. While significant improvement in the ability of physicians to treat many of these diseases only emerged gradually, a systematic understanding of the biological sciences became important for the training of physicians, veterinarians, dentists, and other health workers (Flexner 1910; Ludmerer 1985).

\footnotetext{
${ }^{10}$ The data displayed in Table 1 are taken from Gascoigne (1985), who surveyed and categorized by scientific field approximately 900 scientific periodicals published in Germany, Great Britain, Italy, and the United States throughout the eighteenth and nineteenth century. Our estimates of the number of periodicals published in each discipline in the mid-twentieth century (Table 2) are taken from Fowler (1966), who compiled a list of periodical guides for a variety of academic and professional fields as well as information on the number of periodicals included within each guide.
} 
The consequences of this explosion of specialized knowledge were twofold. First, it became increasingly difficult to be a successful generalist. While it may have been possible in the 1500s for an exceptional individual like Leonardo da Vinci to be an engineer, architect, and physician, it was clearly not feasible to be a master of more than one of these fields by the early 1900s. Therefore, within particular academic disciplines, as well as within particular occupations, specialists emerged who possessed a deeper knowledge of a more specific subject area or application. Second, the benefits of longer and longer periods of formal education increased the pre-requisite knowledge base needed to gain a mastery of certain fields. Completion of primary or even secondary schooling and mastery of "reading, writing, and arithmetic" ceased to furnish an adequate educational background for increasingly specialized and scientific occupations. Universities, colleges, and other institutions of higher learning therefore emerged to educate individuals who wanted to acquire the knowledge and skills to work in occupations where the growth of relevant knowledge was greatest.

The expansion of specialized knowledge and the emergence of "experts" or "professionals" during the late 1800s and early 1900s gave rise to significant changes in the nature of the markets for the services offered by these professionals. In the late eighteenth and early nineteenth centuries, the bulk of the population lived in rural areas or in relatively small towns. While many of the services offered by physicians, dentists, and other professionals were subject to uncertainty, in traditional small town markets, local reputations could play an important role in solving the asymmetric information problem. According to Starr (1982) and Rothstein (1972), markets for physician services during the colonial and early antebellum periods were relatively thin. There were generally very few physicians in each town, and high transportation costs made it impractical to go beyond one's local community in search of medical care. Accordingly, simple reputation mechanisms could work reasonably well in helping consumers evaluate physician quality.

As the nineteenth century progressed, however, falling transportation costs brought about the integration of the national economy, which in turn contributed to regional specialization and urbanization (Kim 1995, 1998, 2000). This movement of the population out of the countryside and into increasingly dense cities was accompanied by 
the rise of impersonal exchange as the dominant form of market interaction.

Specialization and the rise of impersonal exchange created problems for producers and consumers in a wide variety of markets. In the food industry, for instance, urbanization and the rise of impersonal markets for foodstuffs contributed to growing uncertainty about food quality, since consumers knew less and less about how their food was produced and what was added to it (Law 2003). For sellers of professional services, the rise of impersonal market exchange posed similar problems since local reputations became less effective as exchange became increasingly anonymous. Membership in key professional societies or associations may have been a partial substitute for local reputation, but in an environment where professional societies were proliferating in nearly every occupation, and the requirements for membership in these societies were often very low, the signaling value associated with membership in any given society may not have been particularly high (Rothstein 1972). Consequently it became increasingly difficult for professionals to establish a reputation for good service.

Specialization and the rise of impersonal exchange in the market for professional services were accompanied by a sudden surge in state government occupational licensing regulation. ${ }^{11}$ As shown in Table 3, while state governments began to regulate some occupations as early as the 1870 s, most occupational licensing laws were adopted in the first two decades of the 1900s. Some occupations were regulated earlier than others. Physicians and dentists were among the earliest occupations to be regulated as licensing

\footnotetext{
${ }^{11}$ Occupational licensing in America did not begin in the late 1800s. During the colonial period and into the early nineteenth century, state governments regulated the practice of law and medicine in various ways. Nevertheless, occupational licensing on a wide scale did not begin until the late nineteenth century. In the latter half of the 1800s and continuing through the first half of the 1900s, state governments throughout America enacted legislation that regulated a wide variety of occupations. While the substance of these regulations varied from occupation to occupation and from state to state, in general these laws set standards determine what it would involve to become a qualified practitioner of a particular occupation. In some instances, these laws also made it illegal for those who did not meet these standards to practice particular occupations. This second wave of licensing regulation differed from colonial licensing laws in several ways. First, it applied to a wider variety of occupations than medicine and law; the licensing statutes enacted in the late 1800s and early 1900s included occupations ranging from barbers and beauticians to architects, engineers, and dentists. Second, the requirements that were established by these regulations were generally stricter than those that were in place during the colonial era. Although colonial era licensing laws generally did not preclude unlicensed individuals from practicing law or medicine, in the late nineteenth and early twentieth centuries, a license was usually a pre-requisite to practice a given occupation. Third, the enforcement of these more recent regulations was more vigilant than in the colonial era. Indeed, enforcement of these laws was generally placed in the hands of independent or state licensing boards, whose members were largely drawn from the occupational group being licensed. See Council of State Governments (1952).
} 
laws regulating these professions were first adopted in the 1870s; by the early 1900s, most states had enacted some kind of medical or dental licensing regulation. In contrast, the earliest laws regulating accountants, architects, and nurses were generally not enacted until the 1890s and early 1900s. For these occupations, it was not until the 1910s and 1920s that the majority of states had enacted licensing legislation.

\section{Why Did Licensing Arise? An Empirical Analysis}

Was licensing regulation adopted to restrict entry into particular occupations in an attempt to increase the incomes of professionals? Or were licensing laws introduced to reduce asymmetric information about professional quality? Several studies have examined the effects of licensing on entry and on the incomes of certain professionals (e.g. physicians, dentists, nurses) using more contemporary data but to our knowledge no scholarship has analyzed the factors that led to the adoption of initial licensing legislation in the late nineteenth and early twentieth centuries or the effects of these early licensing laws on entry into a wide variety of occupations. Hence, in this section, we exploit crossstate variation in the timing of licensing legislation for eleven different occupations in order to investigate (a) the factors that influenced the adoption of initial licensing legislation; and (b) the impact of licensing on the number of workers per capita in a given occupation. ${ }^{12}$

The primary source for our data on licensing is the Council of State Governments (1952) study, which reports information on when each state adopted licensing legislation for several different occupations. ${ }^{13}$ We matched this with data taken from the decennial population censuses on the number of workers in each occupation. Because the occupational definitions in the population censuses do not always overlap neatly with the occupations that were licensed by state governments, we limited our sample to eleven occupations (architects, attorneys, barbers, beauticians, dentists, engineers, nurses, physicians, plumbers, teachers and veterinarians). This limitation is unfortunate since, as

\footnotetext{
${ }^{12}$ We would also have liked to examine the effect of early licensing laws on the incomes of these eleven occupations. Unfortunately, prior to the 1940s, the Census of Population did not include information on wages or incomes. In section IV, we use the earliest available data on professional incomes to test whether stricter medical licensing laws increased physician incomes in the late 1920s and early 1930s.

${ }^{13}$ For physicians, we use information contained in Baker (1984) on the state medical licensing statutes.
} 
noted earlier, by the 1950s state governments regulated over 75 different occupations. Nevertheless, we believe that these eleven occupations provide us with enough crossoccupational variation to tell a reasonably comprehensive story about the causes and consequences of early licensing laws. We also restricted our attention to the 1880 to 1930 population censuses because the occupational classifications over these years were most consistent (Edwards 1942), and because after 1930, most occupations were already licensed by state governments.

\section{Event History Analysis of the Adoption of Licensing Laws}

To determine what factors motivated state governments to enact licensing regulation, we conduct an event history analysis. In particular, we estimate hazard regressions of the adoption of licensing legislation. Hazard models are appropriate for this purpose because they allow us to exploit the longitudinal structure of our data set. Within the class of hazard models, we use the logistic discrete time hazard model. This is a sensible choice because the adoption of licensing legislation was a single, non-repeated event and because our observations are separated by ten-year intervals along the temporal dimension (Allison 1984).

The basic regression equation we estimate takes the following form:

$$
\log \left[\operatorname{Pr}_{t} /\left(1-P_{t}\right)\right]=\lambda+\theta\left(U_{i t}\right)+\pi\left(L_{i t} / P_{i t}\right)+\rho\left(L_{i t} / P_{i t}\right)^{2}+\varepsilon_{i t}
$$

$\operatorname{Pr}_{t}$ is the probability that occupational licensing legislation for a given occupation is adopted by year $t ; L_{i t} / P_{i t}$ is the per capita number of individuals working in a given occupation in state $i$ in year $t ; U_{i t}$ is the urbanization rate in state $i$ in year $t$; and $\varepsilon_{i t}$ is an error term. The per capita population of individuals working in a given occupation is included to proxy for producer interests. We also include the square of the per capita population of workers in a given occupation to allow for non-linearity in the effect of occupational group size. While increases in the per capita size of the occupational group may lower the time until licensing is adopted (i.e. increase the licensure hazard), the effect of group size may eventually become negative because free riding or coordination problems among members of the group reduces its political effectiveness. The urbanization rate is included as a proxy of the degree to which exchange was impersonal 
in each state, and hence, the extent to which asymmetric information was problematic. ${ }^{14}$ We estimated this equation separately for each of the eleven occupations, and pooled across all eleven occupations. In the pooled regression, the effects of occupational size per capita and its square are constrained to be the same across occupations but each occupation has its own fixed effect. The occupational fixed effect indicates whether a given occupation is more likely to be regulated sooner or later relative to the average time of adoption across all occupations, other things held constant.

Table 4 presents the coefficient estimates when the regression equation was estimated separately for each of the eleven occupations. For architects, attorneys, physicians and veterinarians, urbanization had a positive and statistically significant effect on the licensure hazard, indicating that more urban states were more likely to enact licensing legislation for these occupations sooner. For the other occupations, the coefficient on urbanization is positive but not statistically significant. The per capita number of workers in an occupation had a positive and statistically significant effect on the licensure hazard for barbers, beauticians, dentists, engineers, nurses, physicians, plumbers and veterinarians. Hence, for these occupations, greater producer representation increased the probability that licensing would be adopted sooner.

Table 5 presents the coefficient estimates from the pooled regression. The coefficients on workers per capita, workers per capita squared and urbanization all have the predicted signs and are statistically significant. Additionally the occupational fixed effects indicate that there were occupational-specific differences in the timing of licensing. Barbers are the omitted category and hence the fixed effects should be interpreted as the occupational-specific effect on the timing of licensure relative to barbers. The coefficients indicate that occupations such as architects, attorneys, dentists,

\footnotetext{
${ }^{14}$ Government officials were aware that specialization and urbanization contributed to problems of asymmetric information. For instance, the Council of State Governments (1952, p. 3) made the following argument in favor of licensing regulation: "First, in modern urban society, where great multitudes of people live under increasingly crowded conditions, government agencies become responsible for ensuring adequate knowledge and competence among those ministering to the public health and well-being. This can only be accomplished by defining the conditions of admission and retention into the occupations. Second, the intense specialization in all fields that is characteristics of complex society often means that the public may fail to distinguish between competent and incompetent, honorable and dishonorable practitioners. State occupational licensing agencies therefore perform vital functions in protecting the people from fraud and dishonesty."
} 
nurses, physicians, and veterinarians were regulated earlier than barbers whereas engineers, plumbers, and teachers were regulated later.

The regression results suggest that for most occupations, producer interests were an important factor influencing the timing of licensure, and that for certain professions, the extent to which exchange was anonymous also affected the timing of licensure. Since the producer groups were generally the main proponents of licensing, the statistical significance of producer interests in most of the hazard regressions is not altogether surprising: producer interests probably stood to gain most from licensing, either because they perceived it would function as an entry barrier or because of its potential to reduce informational asymmetries and help make a market for their services. That urbanization also had a positive and significant effect on the licensure hazard for some professions (architects, attorneys, physicians and veterinarians) provides more supporting evidence for the asymmetric information hypothesis. ${ }^{15}$ In addition, the pooled event history analysis suggests that licensing laws were adopted earlier for those professions such as dentists, physicians and veterinarians whose markets were more likely to suffer from problems of asymmetric information.

\section{Effect of licensure on entry}

In this section we conduct an empirical investigation of the effect of early state occupational licensing laws on entry into these eleven occupations. The basic fixed effect regression equation we estimate is as follows:

(1) $L_{i t} / P_{i t}=\mu+S_{i}+Y_{t}+\alpha R_{i t}+X_{i t} \beta+\varepsilon_{i t}$

$P_{i t}$ denotes the population of state $i$ in year $t ; L_{i t}$ denotes the number of workers in a particular occupation in state $i$ in year $t ; S_{i}$ denotes a fixed-effect for state $i ; Y_{t}$ denotes a fixed-effect for year $t$; $R_{i t}$ denotes a binary variable that is equal to 1 in all years $t$ in which occupational licensing is in place in state $i$ and 0 otherwise; and $X_{i t}$ denotes a

\footnotetext{
${ }^{15}$ One potential problem with the urbanization variable is that it might be correlated with political activity among professionals. If the per capita number of workers is correlated with urbanization, then collinearity between urbanization and the per capita number of workers may explain why urbanization is not significant in some of the regressions. To check for this possibility, we re-estimated the regression equations for those occupations where urbanization was not significant excluding the number of workers per capita and its square and we still found that urbanization was not significant. Hence, the failure of urbanization to be significant in these regressions is unlikely to be a consequence of collinearity among the independent variables.
} 
vector of time-varying control variables for state $i$ in year $t$. The two time-varying statelevel control variables we include are (a) the urbanization rate; and (b) real income per capita. ${ }^{16}$ We include these variables because both were likely to influence the per capita number of workers in each occupation. The variable of interest in this regression, $\alpha$, is the coefficient on the regulation dummy variable. If $\alpha<0$ then regulation reduced the number of individuals employed in a particular occupation. If, on the other hand, $\alpha \geq 0$, then regulation either had no impact on entry or increased the entry of individuals into a particular occupation.

We also examine the effect of occupational licensing on entry by estimating a "dynamic" version of equation (1) which takes the following form:

(2) $\quad\left(\% \Delta L_{i t}\right)=\gamma+S_{i}+Y_{t}+\delta\left(\% \Delta P_{i t}\right)+\alpha R_{i t}+v_{i t}$ In regression equation (2), the dependent variable is $\% \Delta L_{i t}$, which is the growth rate between adjacent census years (approximated, for our purposes, by the first difference in the natural logarithm) in the number of individuals working in a given occupation. As before, $\alpha$ is the coefficient of interest. If $\alpha<0$, then occupational licensing regulation reduced the growth rate of the number of persons in a given occupation (i.e. reduced the rate of entry). On the other hand, if $\alpha \geq 0$, then occupational licensing had no impact or increased the growth rate of the number of persons working in a given occupation (i.e. did not affect or increased entry).

Our analysis from the previous section suggests that there is potentially an endogeneity problem with respect to $R_{i t}$, the regulation binary variable, and our dependent variables. The hazard regressions indicated that an increase in the per capita number of workers in a given occupation increased the likelihood that occupational licensing regulation would be enacted. As a result, a positive correlation exists between the regulation binary variable and the error term in equations (1) and (2), which implies that ordinary least squares estimates of the coefficient on the regulation binary variable will be biased. ${ }^{17}$ To address this problem, we instrument for occupational licensing

\footnotetext{
${ }^{16}$ Data on real income per capita at the state level are taken from Kuznets and Brady (1965). Values for 1890 and 1910 were imputed.

${ }^{17}$ To some degree the fixed effect framework should deal with the problem of correlation between the regulation indicator variable and the error term. If the state fixed-effects are capturing unmeasured correlations between the regulation variable and the error, then the coefficient on the regulation binary
} 
regulation. The particular variable we use to instrument for regulation of a given occupation is an index variable that equals the number of other occupations licensed by a given state in a given year. ${ }^{18}$ This is an excellent instrument since it is likely to be correlated with the probability that licensing regulation of a given occupation is enacted but not with the per capita number of workers in that given occupation. ${ }^{19}$ Using this variable as an instrument for occupational licensing regulation for each occupation, we also estimate equations (1) and (2) by two-stage least squares.

Table 6 presents ordinary least squares (OLS) and two stage least squares (2SLS) regression estimates of the effects of licensing regulation on the number of workers per 1,000 persons for each occupation. In none of the regressions is the coefficient on the regulation binary variable negative and significant; early licensing laws do not appear to have reduced the per capita number of workers in any of these occupations, regardless of whether we estimate these regressions by OLS or by 2SLS. For beauticians the coefficient on the regulation dummy is positive and significant in both the 2SLS and OLS regressions suggesting that regulation increased entry into this occupation. In the 2SLS regressions, we find that the coefficient on the regulation variable is negative but not significant for architects, dentists, nurses, physicians, plumbers, and teachers, and positive but not significant for attorneys, barbers, engineers, and veterinarians. The control variables in each of the regression equations generally have plausible signs. For nearly every occupation, urbanization and real per capita income are positively correlated with the number of workers per 1,000.

However, since the enactment of licensing regulation is more likely to have an impact on the rate of entry over time, the dynamic version of the entry restriction regression model is likely to be more informative. Table 7 reports the OLS and 2SLS

variable should be "less positive" when fixed effects are included. We estimated both equations (1) and (2) with and without fixed effects and found that for most occupations, the coefficient on the regulation dummy variable was significantly smaller with state fixed effects than without them. Hence, we believe that the fixed effect framework goes some way in dealing with this problem.

${ }^{18}$ Since we have information on the licensing of eleven occupations, our index variable takes on values from 0 to 10 .

${ }^{19}$ For instance, to instrument for whether physicians were regulated in 1910 in Alabama we construct an index variable that is equal to the total number of other occupations (excluding physicians) licensed by Alabama in 1910. This index variable should be correlated with the probability that physicians were licensed in Alabama in 1910, but not with the per capita number of physicians or the growth rate of physicians in Alabama. 
regression estimates of equation (2) for each occupation. While the OLS estimates suggest that regulation only had a negative and significant effect on the growth rate in the number of architects and veterinarians, the 2SLS estimates suggest that regulation also had a negative and significant effect on the growth rate of physicians and dentists. For beauticians, the coefficient on the regulation variable is positive and significant, but for the remaining occupations, the coefficient on the regulation variable is insignificant. Hence, while regulation may have functioned as an entry barrier for architects, dentists, physicians, and veterinarians, it did not function in this way for the rest of the occupations in our sample.

The regression results therefore suggest that the occupational licensing laws enacted during turn of the century America were negatively correlated with entry for a handful of occupations. For most occupations, licensing did not reduce entry, perhaps because the standards set by most early licensing statutes were not very strict, or because enforcement of early licensing laws was weak. However, it is interesting to note that licensing had a negative effect on entry on physicians, dentists, and veterinariansprofessions whose services tended to be purchased directly by consumers and for which the costs associated with low quality service were potentially greatest - and that licensing did not have a negative effect on entry for engineers and teachers, whose services were generally purchased by firms, or barbers and beauticians, for which the costs of obtaining low quality service were not substantial. ${ }^{20}$

\section{Case study of the medical profession}

We focus on the medical profession for several reasons. First, licensing regulations were rarely static for physicians and it is important to determine which types of regulations were most effective for limiting entry. Second, the availability of data on physician incomes allows us to investigate whether state licensing led to higher incomes. Third, data on health outcomes (i.e. disease-specific mortality rates) can be used to provide a sharper test of whether licensing increased physician quality or reduced competition. Fourth, it is interesting to examine whether medical licensing regulation

\footnotetext{
${ }^{20}$ From this perspective, architects are an outlier, since their services tend to be purchased by firms, rather than individuals and we do find that licensing reduced entry into architecture.
} 
affected the incidence of medical malpractice suits. Finally, because the medical profession was (and continues to be) more strictly regulated than other professions, it is important to determine whether medical licensing improved quality of physician services or merely restricted entry and reduced competition.

Our data on the nature of medical licensing legislation from 1870 to 1930 is taken from Baker (1984) and from the American Medical Association's (AMA) Council on Medical Education. For each state we know (i) the year in which the initial licensing law was enacted; (ii) the year a state licensing board was introduced; (iii) the year in which a state licensing exam was required for new medical license applicants; (iv) the year in which a two-year pre-medical college requirement was introduced; (v) the year in which the length of the medical degree was required to be at least four years long; (vi) the year in which an internship requirement was imposed; and (vii) the year in which a basic science requirement was introduced. By incorporating information on these seven licensing requirements in a regression framework, we hope to control more fully for changes in the nature of medical licensing legislation over time.

Our basic empirical strategy is simple. As before, we match our information on licensing with data on the outcomes that are of interest to us (per capita number of physicians, physician's incomes, disease specific-mortality rates, and the incidence of malpractice suits) and we exploit cross-state variation in licensing to estimate the effect of medical licensing laws on these outcomes in a fixed-effect regression framework. Because our outcome measures are not always available for every state or for the full sample period (1880-1930), sample sizes do vary across regressions. Nevertheless, we believe that the data are rich enough to furnish a nuanced picture of the effects of medical licensing laws.

\section{Effects of medical licensing laws on entry}

Table 8 presents OLS regression estimates of the effects of particular medical licensing requirements on the number of physicians per 1,000 from 1880 to 1930. In the first column we measure licensing by including a binary variable for each of the seven medical licensing requirements. In second column we construct two separate indices to measure early licensing and later licensing requirements separately. Early licensing 
requirements were the initial licensing law and the introduction of a state board. These requirements were generally introduced prior to 1900 . To index for these early requirements we summed the binary variables that indicate whether a state had an initial law and whether the state had a licensing board. Later licensing requirements were those introduced after 1900 (licensing exam, four year medical school requirement, two year premedical college requirement, internship requirement, and the science requirement). The index for these later requirements is a sum of the binary variables that indicate whether the state had introduced these requirements by a given year. Finally, in column (3), we construct a composite licensing index to measure the overall strictness of a state's medical licensing laws. This index is simply the sum of each of the individual binary variables. Since there are seven requirements, this index takes on values between 0 and 7 . As before, we also control for the real per capita income in each state and the urbanization rate in each state to account for other factors that might have influenced the number of physicians per capita.

When we control for each licensing requirement separately (column 1), we find that the introduction of a two-year premedical college requirement and the four-year medical school requirement had a negative and statistically significant impact on the number of physicians per 1,000 persons. Thus, the licensing requirements that restricted entry were those that were most likely to improve physician quality. When we index separately for early and later medical licensing requirements, (column 2) we find that earlier requirements had a positive and significant effect on the number of physicians per 1,000, while later requirements had a negative and significant impact. Hence, it seems that those licensing requirements that were introduced in the post 1900 period were those that were most negatively correlated with entry. ${ }^{21}$ Finally, when we use the composite licensing index to measure overall licensing strictness (column 3), we find that stricter medical licensing reduced the number of physicians per 1,000. Thus, the evidence presented in this set of regressions suggests that medical licensing requirements,

\footnotetext{
${ }^{21}$ Superficially, this would appear to be inconsistent with our analysis in the previous section, which found that initial state licensing regulation reduced entry into medicine. We believe that this is a consequence of the fact that the stricter licensing standards were correlated over time with initial legislation.
} 
particularly those introduced in the early decades of the twentieth century, reduced entry into medicine.

\section{Effects of medical licensing laws on physician incomes}

Perhaps the most highly cited evidence supporting the industry capture explanation for professional licensing comes from the classic study by Friedman and Kuznets (1945). Using survey data on the incomes of physicians and dentists from 1929 to 1932, Friedman and Kuznets found that at a national level, average physician incomes were higher than average dentist incomes. Even after adjusting for the fact that it took longer to become a physician, physicians appeared to earn a premium relative to dentists. Based on this evidence, Friedman and Kuznets attributed this premium to medical licensing regulations that were enacted in response to lobbying by the AMA. In this section, we use the same data on professional incomes to examine whether licensing regulations increased average physician earnings. However, unlike Friedman and Kuznets, we examine whether cross-state variation in physician incomes as well as the ratio of physician to dentist incomes can be explained by variation in the strictness of medical licensing regulation across states.

The data on physician and dental incomes are taken from US Senate (1934). For each state, we know the total earnings of physicians and the number of physicians surveyed. Hence, we divide the total earnings of physicians in each state by the number of physicians surveyed to obtain a measure of average physician earnings and we converted these figures to real 1967 dollars using the CPI. We then matched this data with our information on state-level medical licensing legislation from 1929 to 1932 to estimate the impact of stricter medical licensing regulation on physician earnings. Since, by 1929 , cross state variation in medical licensing regulation was limited to variation in (1) whether the state had a basic science requirement; (2) whether the state had an internship requirement; and (3) whether the state had a premedical college requirement of two years, we restricted our attention to these dimensions of licensing. Because the overall level of income in the state, as well as the extent to which the state was urban may 
have influenced physician incomes, we also include the urbanization rate and the level of personal income per capita. ${ }^{22}$

The onset of the Great Depression may make it difficult to make clean inferences about the effect of medical licensing on physician income. The inclusion of information on real personal income per capita in each state serves as a partial solution to this problem since physician incomes probably declined along with personal incomes during this period. Nevertheless we also include year fixed-effects to control for any nationwide shocks to physician earnings that may have been induced by the Depression. As an alternative solution to this problem, we also examine the impact of medical licensing laws on the ratio of average physician earnings to average dentist earnings in each state. ${ }^{23}$ By using the ratio of physician to dentist earnings, we hope to sweep out state-specific variation in incomes resulting from macroeconomic events.

Columns (1) and (2) in Table 9 display fixed effect OLS regression estimates of the impact of medical licensing legislation on the natural logarithm of average physician incomes from 1929-32. We estimate the effects of licensing on both gross and net physician incomes. We report regression results using the licensing index variable to measure licensing strictness. Qualitatively similar results were obtained when we controlled separately for the various medical licensing requirements.

Surprisingly, the regression coefficients reported in columns (1) and (2) indicate that stricter medical licensing requirements did not have a significant impact on average gross or average net physician earnings. We also investigate the effects of stricter medical licensing requirements on average physician to average dentist incomes in columns (3) and (4). The coefficient on the medical licensing index variable in columns (3) and (4) is not statistically significant, suggesting that licensing also had no effect on the physician to dentist income ratio, regardless of whether we use gross or net income. Hence, cross-

\footnotetext{
${ }^{22}$ Urbanization and real per capita personal income are somewhat collinear. Qualitatively similar coefficient estimates were obtained when we control for only urbanization but not real per capita income (and vice versa).

${ }^{23}$ An examination of the effects of licensing on the ratio of physician to dentist incomes is potentially problematic if (a) dental licensing requirements were changing during the period of study, or if (b) dental licensing varied significantly across states. The available evidence suggests that in the late 1920s and early 1930s, dental licensing requirements did not change much (Friedman and Kuznets 1945; Fraundorf 1984). The inclusion of state fixed-effects should control for any cross-sectional variation in dental licensing across states.
} 
state variation in the same data set used by Friedman and Kuznets does not support their claim that licensing raised physician earnings. Despite the fact that licensing regulations, especially those that lengthened physician training, restricted entry into medical practice, we are unable to find evidence that these same regulations increased physician incomes.

\section{Effects of medical licensing on state-level mortality rates}

In this section we analyze the correlation between licensing and quality by investigating the relationship between physician licensing and mortality. ${ }^{24}$ In the early 1900s, the Census Bureau began to collect disease-specific mortality data at the level of individual states and cities (US Bureau of the Census). By matching this information with our data on state medical licensing regulations, we can estimate the impact of licensing on state mortality rates. Because most of our independent variables are only available at ten year intervals, we collected state level mortality statistics for 1900, 1910, 1920, and 1930.

Since estimates of impact of medical licensing regulation on mortality rates may be subject to an endogeneity problem, we take the following empirical strategy. ${ }^{25}$ First, we include state fixed effects in our analysis in order to sweep out any state-specific factors (for instance, state-specific investments in public health) that may have influenced mortality rates in a given state. Second, we include real per capita income and urbanization as control variables. Urbanization controls for the fact that the disease environment was different in urban areas than in rural areas. Real per capita income is included to proxy for nutritional quality; presumably, average nutrition was better in states with higher real incomes. Third, we examine the impact of licensing not only on

\footnotetext{
${ }^{24}$ A large and growing body of scholarship has been devoted to analyzing the determinants of mortality in America during the twentieth century (Fogel 1994; Preston 1996; Costa and Steckel 1997; Haines 2001). In general, little attention has been paid to the role that medical licensing and improvements in physician quality may have played in reducing mortality rates.

${ }^{25}$ One might imagine that states that were more likely to enact stricter medical licensing requirements were also those states that were more "health conscious." "Health conscious" states may have differed from other states not only in terms of their willingness to adopt stricter medical licensing regulations, but also in terms of their level of public health and/or nutrition. Presumably, the citizens of "health conscious" states enjoyed above average nutrition and were also more willing to invest in public health infrastructure. Hence, mortality may therefore tend to be lower in "health conscious" states, not because stricter licensing improved physician quality, but rather, because investments in public health and better nutrition have altered the disease environment in these states and/or the ability of individuals in these states to fight disease.
} 
overall mortality rates, but also on a few disease-specific mortality rates. While public health investments and/or nutrition may have heavily influenced the probability of dying from certain diseases (for instance, cholera or influenza), the likelihood of dying from other diseases (for instance, appendicitis) may be completely unrelated to nutrition and/or public health.

We collected data on six different mortality rates: the overall mortality rate, cancer mortality rate, diabetes mortality rate, infant mortality rate, maternal mortality rate, and appendicitis mortality rate. To measure the strictness of medical licensing in each state, we used our composite medical licensing index. Table 10 presents OLS regression estimates of the determinants of these six mortality rates. In each regression we control for the urbanization rate in each state, real income per capita, the strictness of medical licensing regulation, state fixed-effects, and the number of physicians per 1,000 persons. $^{26}$

The coefficient estimates of the effects of licensing on mortality suggest that licensing, by increasingly the quality of physicians, lowered mortality rates due to those illnesses where physician quality is likely to have mattered during this period. While stricter medical licensing did not have a significant impact on overall mortality rates, cancer mortality rates, or diabetes mortality rates, they appear to have significantly reduced rates of infant mortality, maternal mortality, and appendicitis mortality. ${ }^{27}$ Stricter licensing should have little effect on overall mortality rates since many causes of death were beyond the control of physicians during this period. In particular, licensing should not affect cancer mortality since the state of medical science at this time was such that even the best physicians were powerless to affect cancer mortality. Increases in physician quality did not significantly lower mortality rates due to diabetes in spite of the fact that the invention of insulin in 1922 provided physicians with a means for treating this illness. However, stricter licensing does seem to have reduced infant and maternal mortality rates since well trained physicians during this period may have been better able to deal with

\footnotetext{
${ }^{26}$ We include the number of physicians per 1,000 persons to control for variation in physician access.

${ }^{27}$ Qualitatively similar results were obtained when we used the lagged value of the composite licensing index to control for physician quality.
} 
complications arising from childbirth. ${ }^{28}$ Finally, states with stricter licensing had lower appendicitis mortality rates. This period witnessed dramatic improvements in basic surgery due to advances in antiseptics. Since the onset of appendicitis is more or less random, this estimate is least likely to be influenced by an endogeneity bias.

The coefficients on the remaining control variables are worth discussing briefly. While the urbanization variable is generally not significant, it appears that the lack of significance of urbanization is due to the inclusion of state fixed effects. When we omit the fixed effects in the regressions, the urbanization coefficient generally becomes significant with the correct sign and the signs and significance levels of the other variables remain unchanged. Real income per capita has a negative and significant impact on overall mortality and infant mortality, a positive and significant effect on appendicitis and diabetes mortality, and a positive but not significant impact on maternal and cancer mortality. That higher real income per capita should reduce overall mortality and infant mortality is unsurprising since nutrition (and hence the ability to fight infection) was probably increasing with income. The absence of a significant correlation between cancer and real income also seems reasonable. The positive and significant correlation between real per capita income and diabetes and appendicitis mortality is somewhat puzzling, but the size of these coefficients is small.

The coefficient on physicians per 1,000 persons, which proxies for physician access, is positive but not significant in the overall mortality rate regression; negative but not significant in the cancer, infant, and maternal mortality rate regressions; and negative and significant in the diabetes and appendicitis mortality rate regressions. While access to a physician may not have been important for overall mortality or cancer mortality (since physicians were powerless to treat most illnesses at this time), it may have been important for diabetes mortality (since physicians were important conveyors of insulin treatment) and appendicitis mortality (since surgery requires access to a physician). Finally, access to physicians may not have been critical for infant or maternal mortality rates because of the availability of midwives as a substitute, although it is worth noting

\footnotetext{
${ }^{28}$ Collins and Thomasson (2002) examine whether the racial gap in infant mortality rates from 1920 to 1970 at the state level can be explained by differences in income, urbanization, women's education and physicians per capita.
} 
that physician quality (as proxied by the licensing index) did matter for these causes of mortality.

\section{Effects of medical licensing regulation on state-level appellate court malpractice suits}

In this section, we examine the relationship between state medical licensing requirements and the incidence of medical malpractice suits. In principle, if licensing requirements increased physician quality, then one might expect to observe a reduction in the number of malpractice suits in response to medical licensing legislation. However, the frequency of medical malpractice suits seems to have increased dramatically over the Progressive Era. According to De Ville (1990), the growth in malpractice suits during this period was caused by competition among physicians of different sects as well as dramatic advances in medical technology.

Our data on malpractice cases is taken from Smith (1941c), who reports the number of appeals court cases on medical malpractice over each decade and in each state from 1790 to 1940 . We restrict our attention to the data from 1880 to 1930 since this overlaps with our data on medical licensing regulations. Ideally we would have liked to use data on the total number of malpractice cases rather than merely the number of cases reaching state appeals courts. However, to the extent that the number of malpractice cases reaching state appeals courts is positively correlated with the total number of malpractice cases in a given state, the data reported in Smith (1941c) should serve as a reasonable proxy for the incidence of malpractice suits in each state.

Since we expect that the number of malpractice cases should be greater in more populous states, we normalize Smith's data by state population (in millions) to obtain our dependent variable. Because Smith reports the number of appellate court malpractice cases filed over a decade, our dependent variable is the cumulative number of appellate court cases in a given state over the decade per million persons in a given state at the beginning of the decade. As control variables, we include state fixed effects, the number of physicians per 1,000 persons, the urbanization rate, real per capita income, and medical licensing variables. Our time varying control variables (physicians per 1,000, urbanization, real per capita income, and medical licensing) are matched with the dependent variable so they control for conditions as they existed at the beginning of the 
decade. We also include a time trend to sweep out factors that may have contributed to an overall rise in litigation during this period.

Fixed effect OLS regression estimates of the determinants of medical malpractice are displayed in Table 11. In column (1), we use separate binary variables to control for each of our seven medical licensing requirements. Surprisingly, the data indicate that certain licensing requirements - specifically, the presence of a licensing exam and the four year medical degree requirement-significantly increased the incidence of medical malpractice suits. In columns (2), (3) and (4) we group the medical licensing requirements in different ways and continue to find a positive and significant relationship between medical licensing and the frequency of medical malpractice suits. ${ }^{29}$ Thus, despite the fact that licensing is likely to have raised overall physician quality, licensing led to an increase rather than a decrease in medical malpractice suits. ${ }^{30}$

We believe that there is a plausible explanation for why licensing may have increased the incidence of medical malpractice suits. Throughout the Progressive Era, as well as for most of the modern period, the courts ruled on medical malpractice suits based on standards of care available in a given locality (De Ville 1990). When licensing

\footnotetext{
${ }^{29}$ In order to determine whether the lack of significance of some of these medical licensing requirements was due to collinearity among these binary variables, we grouped together the requirements in various ways. In column (2) we control for the presence of an exam and the four year medical degree requirement separately, but we group the initial licensing law and state board together, and the college, internship, and science requirements together. In this regression, the index variable that measures the college, internship, and science requirements jointly is now positive and significant, as are the licensing exam and four year medical school requirement. Hence, this regression suggests that the college, internship, and science requirements may also have contributed to a rise in the incidence of medical malpractice suits. However, the index that measures the presence of an initial licensing law and a state board is still not significant. In column (3) we group licensing requirements into two categories: early requirements (initial law and the presence of a state board) and later requirements (the remaining five requirements). We find that later requirements had a positive and significant effect on the incidence of malpractice suits, but early requirements did not. Finally, in column (4), we combine all of these medical licensing requirements into a composite licensing index to measure the overall strictness of licensing regulations and find that increases in the index increased the incidence of malpractice suits. In each regression the Durbin-Watson statistic is close to 2 , which indicates that serial correlation in the residuals is unlikely to be problematic.

${ }^{30}$ The positive correlation we observe between licensing and the incidence of medical malpractice suits may be biased if stricter licensing laws were adopted in response to increases in the frequency of medical malpractice suits. To test for this source of endogeneity, we estimated a regression of the composite licensing index in a given state in year $t+10$ on the number of malpractice cases per million over the decade between $t$ and $t+10$ and the other control variables discussed earlier. In this regression, the coefficient on the number of malpractice cases per decade per million persons was negative but not significantly different from zero, which suggests that stricter licensing requirements were not enacted in response to malpractice cases. Qualitatively similar results were obtained when other measures of licensing were used in place of the composite licensing index as the dependent variable. Hence, we believe we can rule out this source of endogeneity bias.
} 
requirements did not exist, the standards of local practice were difficult to define because anyone could legally call himself a physician. Licensing regulations, by better defining the standards of local practice, may have made it easier for patients to successfully sue physicians. In this vein, it is noteworthy that Smith (1941a-d) finds that most medical malpractice suits were filed against ordinary physicians rather than quacks. While medical licensing may have eliminated "charlatans" and "quacks," it probably did not eliminate all incompetent doctors. Licensing legislation may therefore have increased the incidence of medical malpractice suits because it made it less costly for consumers to sue negligent and unqualified doctors for poor outcomes.

\section{Conclusions}

The Progressive Era marked the transition period when the United States was transformed from a traditional to a modern society. During this period, with advances in science and knowledge based on ever increasing specialization, modern professionals emerged in numerous occupations. As the spatial organization of society moved away from one based on villages and small towns to large urban areas, market exchanges became more impersonal and anonymous. Specialization and the rise of impersonal exchange were accompanied by an expansion of the role of government in the economy. In this paper, we examine why state governments began to regulate the professional labor market at this time.

We believe that the emergence of professional licensing regulation during the Progressive Era was motivated by a desire to improve the market for professional services. During this period, the growth of specialization and impersonal exchange gave rise to "lemons" problems in the market for professional services. But, because private mechanisms alone could not eliminate all unqualified practitioners from the market, it was necessary for state governments to enact regulations that set standards of qualification to practice these occupations. Our analysis finds that licensing legislations were adopted earlier and were more likely to restrict entry into professions where informational asymmetries were most likely to be problematic. In addition, a detailed study of the effects of medical licensing shows that licensing regulation did not raise physician incomes but may have increased physician quality. 
When the Council of State Governments met in 1951 to request a survey of the professional and occupational licensing practices of states, it was aware that state licensing powers could be used not only as an instrument to "protect the safety and welfare" of consumers, but also as a device to create "monopoly conditions." However, when the survey was reported in 1952, the Council reached no definitive conclusions regarding which of these forces was more important. While we believe that the evidence from the Progressive Era is more consistent with a public interest explanation for licensing regulation than one based on industry capture, we, like the skeptical midwestern Governor quoted in our introduction, cannot dismiss the fact that licensing regulations also "lay the foundation for creating monopolies that inhibit market competition" (Council of State Governments 1952, p. 1). We hope that future scholars will take up the task to determine if and when licensing regulations became a tool to advance the narrow interests of professionals at the expense of the general public. 


\section{References}

Akerlof, George (1970). “The Market for 'Lemons': Quality Uncertainty and the Market Mechanism." Quarterly Journal of Economics 84: 488-500.

Allison, Paul D. (1984). Event History Analysis: Regression for Longitudinal Event Data. Beverly Hills: Sage Publications.

Arrow, Kenneth J. (1963). "Uncertainty and the Welfare Economics of Medical Care." American Economic Review 53: 941-973.

Baker, Samuel L. (1984). "Physician Licensure Laws in the United States, 1865-1915." Journal of the History of Medicine and Allied Sciences 39: 173-197.

Benham, Lee and Alexandra Benham (1975). "Regulating Through the Professions: A Perspective on Information Control." Journal of Law and Economics 18: 421-447.

Benham, Lee, A. Maurizi and M. Reder (1968). Migration, Location, and Remuneration of Medical Personnel: Physicians and Dentists." Review of Economics and Statistics 50: $332-347$.

Burnstein, P.L. and J. Cromwell (1985). "Relative Incomes and Rates of Return for US Physicians." Journal of Health Economics 4: 63-78.

Calvert, Monte A. (1967). The Mechanical Engineer in America, 1830-1910:

Professional Cultures in Conflict. Baltimore: Johns Hopkins University Press.

Caroll, Sindey L. and Robert J. Gaston (1981). "Occupational Restrictions and the

Quality of Service Received: Some Evidence.” Southern Economic Journal 48: 959-975.

Collins, William J. and Melissa A. Thomasson (2002). "Exploring the Racial Gap in Infant Mortality Rates, 1920-1970,” NBER Working Paper No. 8836.

Costa, Dora L. and Richard H. Steckel (1997). "Long-Term Trends in Health, Welfare, and Economic Growth in the United States." In R. Steckel and R. Floud (eds.). Health and Welfare During Industrialization. Chicago: University of Chicago Press.

Council of State Governments (1952). Occupational Licensing Legislation in the States. Chicago: Council of State Governments.

Council on Medical Education (1920). "Medical Education in the United States." Journal of the American Medical Association, 76: 379-388.

Council on Medical Education (1930). "Medical Education in the United States." Journal of the American Medical Association, 95: 487-524. 
Cutler, David M. and Ellen Meara (2001). "Changes in the Age Distribution of Mortality Over the $20^{\text {th }}$ Century." NBER Working Paper No. 8556.

De Ville, Kenneth Allen (1990). Medical Malpractice in Nineteenth Century America:

Origins and Legacy. New York: New York University Press.

Edwards, Alba M. (1942). Comparative Occupation Statistics for the United States, 1870 to 1940. Washington, DC: GPO.

Feldman, Roger and James W. Begun (1985). "The Welfare Cost of Quality Changes Due to Professional Regulation.” Journal of Industrial Economics 34: 17-32

Flexner, Abraham (1910). Medical Education in the United States and Canada: A Report to the Carnegie Foundation for the Advancement of Teaching. New York: Carnegie Foundation.

Fogel, Robert W. (1994). "Economic Growth, Population Theory, and Physiology: The Bearing of Long-Term Processes on the Making of Economic Policy." American Economic Review 84: 369-395.

Fowler, Maureen J. (1966). Guides to Scientific Periodicals. London: The Library Association.

Friedman, Milton (1962). Capitalism and Freedom. Chicago: University of Chicago Press.

Friedman, Milton and Simon Kuznets (1945). Income from Independent Professional Practice. New York: National Bureau of Economic Research.

Fraundorf, Kenneth C. (1984). "Organized Dentistry and the Pursuit of Entry Control." Journal of Health Politics, Policy, and Law 8: 759-781.

Fuchs, Victor R., (ed.) (1969). Production and Productivity in the Service Industries. Studies in Income and Wealth, Volume 34. New York: Columbia University Press.

Gascoigne, Robert M. (1985). A Historical Catalogue of Scientific Periodicals, 1665 1900. New York: Garland Publishing.

Graddy, Elizabeth (1991). "Toward a General Theory of Occupational Licensure." Social Science Quarterly 72: 676-695.

Haas-Wilson, Deborah (1986). "The Effect of Commercial Practice Restrictions: The Case of Optometry." Journal of Law and Economics 29: 165-186.

Haines, Michael (2001). "The Urban Mortality Transition in the United States, 18001940,” NBER Historical Paper No. 134. 
Holen, Arlene (1965). "Effects of Professional Licensing Arrangements on Interstate Mobility and Resource Allocation.” Journal of Political Economy 73: 492-498.

Kessel, Reuben (1970). "The AMA and the Supply of Physicians.” Law and Contemporary Problems 35: 267-283.

Kessel, Reuben (1972). "Higher Education and the Nation's Health: A Review of the Carnegie Commission Report on Medical Education." Journal of Law and Economics 15: 115-127.

Kim, Sukkoo (1995). "The Expansion of Markets and the Geographic Distribution of Economic Activities: Trends in US Regional Manufacturing Structure, 1860-1987.” Quarterly Journal of Economics 110: 881-908.

Kim, Sukkoo (1998). "Economic Integration and Convergence: US Regions, 1840-1987." Journal of Economic History 58: 659-683.

Kim, Sukkoo (2000). "Urban Development in the United States, 1690-1990." Southern Economic Journal 66: 855-880.

Kuznets, Simon and Dorothy S. Thomas (eds.) (1965). Population Redistribution and Economic Growth: United States 1870-1950. Philadelphia: American Philosophical Society.

Law, Marc T. (2003). "The Origins of State Pure Food Regulation.” Journal of Economic History, 63: 1103-1130.

Leland, Hayne (1979). "Quacks, Lemons and Licensing: A Theory of Minimum Quality Standards.” Journal of Political Economy 87: 1328-1346.

Leffler, Keith B. (1978). "Physician Licensure: Competition and Monopoly in American Medicine." Journal of Law and Economics 21: 165-186.

Ludmerer, Kenneth M. (1985). Learning to Heal: The Development of American Medical Education. New York: Basic Books.

Maurizi, Alex R. (1974). “Occupational Licensing and the Public Interest.” Journal of Political Economy 82: 399-413.

Merriam-Webster Inc. (1997). Merriam-Webster Dictionary. Springfield, MA: MerriamWebster.

Moore, Thomas (1964). "The Purpose of Licensing." Journal of Law and Economics 4: 93-117. 
Noerther, Monica (1986). "The Effect of Government Policy Changes on the Supply of Physicians: Expansion of a Competitive Fringe." Journal of Law and Economics 29: 231262.

Pashigian, B. Peter (1979). "Occupational Licensing and the Interstate Mobility of Professionals." Journal of Law and Economics 22: 1-25.

Preston, Sam (1996). “American Longevity: Past, Present, and Future.” Syracuse University Policy Brief No. 7. Distinguished Lecturer in Aging Series, Center for Economic Policy Research.

Price, Derek J. deSolla (1963). Little Science, Big Science. New York: Columbia University Press.

Rothstein, William (1972). American Physicians of the Nineteenth Century: From Sects to Science. Baltimore: Johns Hopkins University Press.

Smith, Hubert Winston (1941a). "Legal Responsibility for Medical Malpractice: The Legal Matrix of Medical Malpractice." Journal of the American Medical Association 116 (16): 942-947.

Smith, Hubert Winston (1941b). "Legal Responsibility for Medical Malpractice. Malpractice: Something of the Anatomy of the Law." Journal of the American Medical Association 116 (19): 2149-2159.

Smith, Hubert Winston (1941c). "Legal Responsibility for Medical Malpractice: Malpractice Claims in the United States and a Proposed Formula for Testing Their Legal Sufficiency." Journal of the American Medical Association 116 (24): 2670-2679.

Smith, Hubert Winston (1941d). "Legal Responsibility for Medical Malpractice: Further Information about Direct Causation and Damage." Journal of the American Medical Association 117 (1): 23-33.

Society for the Promotion of Engineering Education (1930). Report of the Investigation of Engineering Education: Volume I. Lancaster: Lancaster Press.

Starr, Paul (1982). The Social Transformation of American Medicine: The Rise of a Sovereign Profession and the Making of a Vast Industry. New York: Basic Books.

Stevens, Robert (1983). Law School: Legal Education in America from the 1850s to the 1980s. Chapel Hill: University of North Carolina Press.

Stigler, George (1971). "The Theory of Economic Regulation.” Bell Journal of Economics and Management Science. 2: 3-21. 
Svorney, Shirley V. (1987). "Physician Licensure: A New Approach to Examining the Role of Professional Interests." Economic Inquiry 25: 497-509.

US Bureau of the Census (various years). Census of Population. Washington, DC: GPO.

US Bureau of the Census (various years). Mortality Statistics. Washington, DC: GPO.

US Department of Commerce (2001). Statistical Abstract of the United States. Washington, DC: GPO.

US Senate (1934). "National Income, 1929-32." Senate Document No. 124, $73^{\text {rd }}$ Congress, $2^{\text {nd }}$ Session, $v$.

Wallis, John J. and Douglass C. North (1986). "Measuring the Transaction Sector of the American Economy, 1870-1970." In Engerman, Stanley and Robert Gallman (eds.). Long Term Factors in American Economic Growth. Chicago: University of Chicago Press, pp. 85-148.

Weingast, Barry (1980). "Physicians, DNA Research Scientists, and the Market for Lemons." In Blair, Roger D. and Stephen Rubin (eds.). Regulating the Professions: A Public Policy Symposium. Lexington: DC Heath and Company, pp. 81-96.

White, William (1980). "Mandatory Licensure of Registered Nurses: Introduction and Impact.” In Rottemburg, Simon (ed.) (1980). Occupational Licensure and Regulation. Washington, DC: American Enterprise Institute. 
Table 1: Specialization among scientific periodicals, 1780-1900

A. Number of periodicals by scientific field

\begin{tabular}{lccccccc}
\hline & 1780 & 1800 & 1820 & 1840 & 1860 & 1880 & 1900 \\
\hline General science & 27 & 34 & 45 & 69 & 124 & 181 & 218 \\
Astronomy & 0 & 1 & 1 & 3 & 6 & 9 & 23 \\
Botany & 0 & 2 & 3 & 11 & 22 & 33 & 59 \\
Chemistry & 1 & 7 & 7 & 14 & 18 & 25 & 48 \\
Experimental biology & 0 & 1 & 1 & 2 & 11 & 21 & 49 \\
Geography & 0 & 0 & 0 & 5 & 12 & 20 & 28 \\
Geology & 0 & 2 & 6 & 15 & 28 & 46 & 79 \\
Mathematics & 0 & 0 & 1 & 3 & 8 & 28 & 45 \\
Natural history & 2 & 3 & 5 & 20 & 40 & 60 & 72 \\
Physics & 0 & 1 & 1 & 3 & 4 & 11 & 25 \\
Zoology & 0 & 0 & 2 & 14 & 27 & 52 & 109 \\
Other & 0 & 0 & 0 & 1 & 4 & 19 & 38 \\
Total & 30 & 51 & 72 & 160 & 304 & 505 & 793 \\
\hline
\end{tabular}

B. Percentage of periodicals by scientific field

\begin{tabular}{lccccccc}
\hline & 1780 & 1800 & 1820 & 1840 & 1860 & 1880 & 1900 \\
\hline General science & 90.0 & 66.6 & 62.5 & 43.1 & 40.8 & 35.8 & 27.5 \\
Astronomy & 0 & 2.0 & 1.4 & 1.9 & 2.0 & 1.8 & 2.9 \\
Botany & 0 & 3.9 & 4.2 & 6.8 & 7.2 & 6.5 & 7.4 \\
Chemistry & 3.3 & 13.7 & 9.7 & 8.8 & 6.0 & 5.0 & 6.0 \\
Experimental biology & 0 & 2.0 & 1.4 & 1.2 & 3.6 & 4.1 & 6.2 \\
Geography & 0 & 0 & 0 & 3.1 & 3.9 & 4.0 & 3.5 \\
Geology & 0 & 3.9 & 8.3 & 9.4 & 9.2 & 9.1 & 10.0 \\
Mathematics & 0 & 0 & 1.4 & 1.9 & 2.6 & 5.5 & 5.7 \\
Natural history & 6.7 & 5.9 & 6.9 & 12.5 & 13.2 & 11.9 & 9.1 \\
Physics & 0 & 2.0 & 1.4 & 1.9 & 1.3 & 2.2 & 3.2 \\
Zoology & 0 & 0 & 2.8 & 8.8 & 8.9 & 10.3 & 13.7 \\
Other & 0 & 0 & 0 & 0.6 & 1.3 & 3.8 & 4.8 \\
Total & 100 & 100 & 100 & 100 & 100 & 100 & 100 \\
\hline
\end{tabular}

Source: Adopted from the tables contained in Part 3 of Gascoigne (1985). 
Table 2: Mid-twentieth century specialization in scientific knowledge

A. Pure scientific fields

\begin{tabular}{|c|c|c|c|}
\hline & $\begin{array}{l}\text { Approximate number of } \\
\text { periodicals in field }\end{array}$ & Year & Source \\
\hline Astronomy & $\begin{array}{l}650 \text { periodicals "not } \\
\text { known to have ceased } \\
\text { publication" }\end{array}$ & 1958 & $\begin{array}{l}\text { Crane, Louis F. (1958). An International } \\
\text { Bibliography of Current Astronomical } \\
\text { Serials. Ann Arbor: University of Michigan } \\
\text { Press }\end{array}$ \\
\hline Biology & 5,000 "current titles" & 1960 & $\begin{array}{l}\text { "Biological Abstracts List of Serials," } \\
\text { Biological Abstracts, 35: 4703-4742 }\end{array}$ \\
\hline Chemistry & $\begin{array}{l}1,560 \text { "current and } \\
\text { discontinued titles" }\end{array}$ & 1960 & $\begin{array}{l}\text { Chemical Society (1960). Periodicals in the } \\
\text { Chemical Society Library. London }\end{array}$ \\
\hline Geography & 657 "current titles" & 1961 & $\begin{array}{l}\text { Royal Geographical Society (1961). Current } \\
\text { Geographical Periodicals: A Hand-list and } \\
\text { Subject Index of Current Periodicals in the } \\
\text { Library of the RGS. London: RGS }\end{array}$ \\
\hline Mathematics & 800 titles & circa 1965 & $\begin{array}{l}\text { American Mathematical Society, } \\
\text { Mathematical Reviews. }\end{array}$ \\
\hline Physics & 850 "current titles" & 1950 & $\begin{array}{l}\text { Bray, Robert S (1950). List of Periodicals of } \\
\text { Physics Interest. Washington DC: Office of } \\
\text { Technical Services }\end{array}$ \\
\hline
\end{tabular}

B. Scientific professions

\begin{tabular}{|c|c|c|c|}
\hline & $\begin{array}{l}\text { Approximate number of } \\
\text { periodicals in field }\end{array}$ & Year & Source \\
\hline Dentistry & $\begin{array}{l}1,255 \text { "current and } \\
\text { discontinued titles" }\end{array}$ & 1962 & $\begin{array}{l}\text { Schmidt, Hans Joachim (1962). List of Dental } \\
\text { Periodicals. Stuttgart-Degerlock: Verlag der } \\
\text { Deutschen Doukumentenstelle für } \\
\text { zahnärztliches Schrifttum. }\end{array}$ \\
\hline Engineering & 553 "current titles" & 1953 & $\begin{array}{l}\text { Association of College and Reference } \\
\text { Libraries (1953). A Recommended List of } \\
\text { Basic Periodicals in Engineering and } \\
\text { Engineering Sciences. Chicago: ACRL. }\end{array}$ \\
\hline Medicine & 2,700 "current titles" & circa 1965 & $\begin{array}{l}\text { Index Medicus, Washington, DC: Public } \\
\text { Health Service }\end{array}$ \\
\hline Pharmacy & $\begin{array}{l}935 \text { "current and } \\
\text { discontinued periodicals" }\end{array}$ & 1963 & $\begin{array}{l}\text { Andrews, Theodora (1963). World List of } \\
\text { Pharmacy Periodicals. Washington, DC: } \\
\text { American Society of Hospital Pharmacists. }\end{array}$ \\
\hline $\begin{array}{l}\text { Veterinary } \\
\text { Medicine }\end{array}$ & 570 "current titles" & 1961 & $\begin{array}{l}\text { Commonwealth Bureau of Animal Health } \\
\text { (1961). "List of Publications Searched by the } \\
\text { Commonwealth Bureau of Animal Health." } \\
\text { Veterinary Bulletin 31: i-ix. }\end{array}$ \\
\hline
\end{tabular}

Source: Information in this table is taken from Fowler (1966) 
Table 3: The timing of licensing regulations: number of states enacting licensing regulation by 10 year interval for selected occupations, 1870-1950

\begin{tabular}{|c|c|c|c|c|c|c|c|c|c|c|c|}
\hline Profession & Pre 1870 & $1871-80$ & $1881-90$ & $1891-1900$ & $1901-10$ & 1911-20 & $1921-30$ & $1931-40$ & $1941-50$ & Timing Unknown & Total \\
\hline Accountants & & & & 3 & 18 & 25 & 1 & 1 & & & 48 \\
\hline Architects & & & & 1 & 6 & 11 & 12 & 10 & 6 & & 46 \\
\hline Attorneys & 10 & 1 & 1 & 4 & 5 & 2 & 5 & 4 & & 16 & 48 \\
\hline Barbers & & & & 2 & 11 & 1 & 12 & 15 & 1 & 4 & 46 \\
\hline Beauticians & & & & & & 1 & 20 & 21 & 3 & & 45 \\
\hline Chiropractors & & & & 1 & & 17 & 21 & 4 & 1 & & 44 \\
\hline Dentists & 2 & 4 & 21 & 10 & 5 & 4 & 1 & 1 & & & 48 \\
\hline Electricians & & & & & 1 & 2 & & & 2 & 4 & 9 \\
\hline Engineers & & & & & 1 & 10 & 14 & 15 & 8 & & 48 \\
\hline Insurance Brokers & 1 & & & 1 & 3 & 8 & 1 & 3 & & 5 & 22 \\
\hline Midwives & & & & 4 & 2 & 5 & 1 & 1 & & 1 & 14 \\
\hline Practical Nurses & & & & & 5 & 2 & 1 & 1 & 15 & 8 & 32 \\
\hline Registered Nurses & & & & & 23 & 20 & 4 & 1 & & & 48 \\
\hline Optometrists & & & & & 15 & 21 & 5 & 1 & & 6 & 48 \\
\hline Osteopaths & & & & 8 & 19 & 8 & 3 & & 1 & 8 & 47 \\
\hline Pharmacists & & 7 & 24 & 10 & 4 & 1 & & 2 & & & 48 \\
\hline Physical therapists & & & & & & 1 & 1 & & 2 & 5 & 9 \\
\hline Physicians & 5 & 15 & 22 & 6 & & & & & & & 48 \\
\hline Plumbers & & & & & 2 & 2 & & 3 & 6 & 3 & 16 \\
\hline Psychologists & & & & & & & & & 3 & & 3 \\
\hline Real Estate Brokers & & & & & & 6 & 23 & 6 & 5 & & 40 \\
\hline Surveyors & & & & & 2 & 4 & 3 & 3 & 1 & 20 & 33 \\
\hline Teachers & 10 & 1 & 2 & 2 & 2 & 4 & 1 & & & 26 & 48 \\
\hline Veterinarians & & & 2 & 7 & 15 & 11 & 3 & & & 10 & 48 \\
\hline
\end{tabular}

Source: Adopted from Table A in Council of State Governments (1952). For physicians, the data are taken from Baker (1984). 
Table 4: Discrete time hazard model estimates of the factors influencing the adoption of licensing regulation

\begin{tabular}{|c|c|c|c|c|c|c|c|c|c|c|c|}
\hline & Architect & Architect & Attorney & Attorney & Barber & Barber & Beautician & Beautician & Dentist & Dentist & Engineer \\
\hline Constant & $\begin{array}{c}-3.01 * * * \\
(0.39)\end{array}$ & $\begin{array}{c}-3.00 * * * \\
(0.40)\end{array}$ & $\begin{array}{l}-1.55^{*} \\
(0.82)\end{array}$ & $\begin{array}{l}-2.17^{*} \\
(1.20)\end{array}$ & $\begin{array}{c}-8.31 * * * \\
(1.81)\end{array}$ & $\begin{array}{c}-9.01 * * * \\
(2.24)\end{array}$ & $\begin{array}{c}-6.20 * * * \\
(1.07)\end{array}$ & $\begin{array}{c}-6.26 * * * \\
(1.14)\end{array}$ & $\begin{array}{c}2.93 * * * \\
(0.63)\end{array}$ & $\begin{array}{c}-3.44 * * * \\
(0.66)\end{array}$ & $\begin{array}{c}-3.67 * * * \\
(0.47)\end{array}$ \\
\hline Urbanization & $\begin{array}{l}1.74^{*} \\
(1.00)\end{array}$ & $\begin{array}{l}1.69 * \\
(1.00)\end{array}$ & $\begin{array}{l}2.53 * * \\
(1.05)\end{array}$ & $\begin{array}{l}2.31 * * \\
(1.01)\end{array}$ & $\begin{array}{l}-0.84 \\
(0.96)\end{array}$ & $\begin{array}{c}0.17 \\
(1.49)\end{array}$ & $\begin{array}{l}-2.57 \\
(1.72)\end{array}$ & $\begin{array}{l}-1.65 \\
(1.97)\end{array}$ & $\begin{array}{c}0.98 \\
(1.01)\end{array}$ & $\begin{array}{c}1.34 \\
(1.08)\end{array}$ & $\begin{array}{l}-0.48 \\
(0.89)\end{array}$ \\
\hline $\begin{array}{l}\text { Workers per } \\
\text { thousand }\end{array}$ & $\begin{array}{l}2.20 \\
(5.16)\end{array}$ & $\begin{array}{l}2.61 \\
(5.11)\end{array}$ & $\begin{array}{l}-0.88 \\
(1.10)\end{array}$ & $\begin{array}{l}-0.96 \\
(1.16)\end{array}$ & $\begin{array}{c}6.17 * * * \\
(0.96)\end{array}$ & $\begin{array}{l}4.60 * \\
(2.71)\end{array}$ & $\begin{array}{c}13.32 * * * \\
(2.61)\end{array}$ & $\begin{array}{l}8.25 * * \\
(3.95)\end{array}$ & $\begin{array}{c}7.10 * * * \\
(2.52)\end{array}$ & $\begin{array}{l}5.33 * \\
(3.18)\end{array}$ & $\begin{array}{c}1.51 * * * \\
(0.93)\end{array}$ \\
\hline (Workers per & 1.34 & 0.94 & 0.24 & 0.29 & $-1.25 * *$ & -1.11 & $-5.43 * * *$ & -3.37 & $-3.62 * *$ & $-3.15^{*}$ & $-0.16^{*}$ \\
\hline thousand $)^{\frac{1}{2}}$ & $(9.56)$ & $(9.83)$ & $(0.30)$ & $(0.29)$ & $(0.58)$ & $(0.74)$ & $(1.83)$ & $(2.13)$ & $(1.54)$ & $(1.88)$ & $(0.09)$ \\
\hline $\begin{array}{l}\text { Time varying } \\
\text { hazard }\end{array}$ & No & Yes & No & Yes & No & Yes & No & Yes & No & Yes & No \\
\hline $\begin{array}{l}\text { Log- } \\
\text { likelihood }\end{array}$ & -93.13 & -93.04 & -38.56 & -35.41 & -76.39 & -56.73 & -37.48 & -35.63 & -86.93 & -73.53 & -75.13 \\
\hline $\mathrm{N}$ & 284 & 284 & 83 & 83 & 286 & 286 & 329 & 329 & 162 & 162 & 312 \\
\hline & Engineer & Nurse & Nurse & Physician & Physician & Plumber & Plumber & Teachers & Teachers & Vets & Vets \\
\hline Constant & $\begin{array}{c}-5.32 * * * \\
(1.25)\end{array}$ & $\begin{array}{c}-4.39 * * * \\
(0.48)\end{array}$ & $\begin{array}{c}-4.91 * * * \\
(0.20)\end{array}$ & $\begin{array}{c}-6.11 * * \\
(2.54)\end{array}$ & $\begin{array}{c}3.49 * * * \\
(0.78)\end{array}$ & $\begin{array}{c}-6.23 * * * \\
(1.16)\end{array}$ & $\begin{array}{c}-6.92 * * * \\
(1.07)\end{array}$ & $\begin{array}{c}-6.85 * * \\
(3.07)\end{array}$ & $\begin{array}{c}-5.95 * * \\
(2.95)\end{array}$ & $\begin{array}{c}-3.67 * * * \\
(0.56)\end{array}$ & $\begin{array}{c}-3.08 * * * \\
(0.64)\end{array}$ \\
\hline Urbanization & $\begin{array}{l}-2.49 \\
(1.77)\end{array}$ & $\begin{array}{c}1.28 \\
(0.95)\end{array}$ & $\begin{array}{c}1.47 \\
(1.18)\end{array}$ & $\begin{array}{l}1.53 * \\
(0.83)\end{array}$ & $\begin{array}{l}1.49^{*} \\
(0.85)\end{array}$ & $\begin{array}{l}-1.63 \\
(1.46)\end{array}$ & $\begin{array}{c}0.22 \\
(1.66)\end{array}$ & $\begin{array}{c}0.48 \\
(2.10)\end{array}$ & $\begin{array}{l}-0.08 \\
(2.25)\end{array}$ & $\begin{array}{c}3.32 * * * \\
(1.10)\end{array}$ & $\begin{array}{c}3.69 * * * \\
(1.30)\end{array}$ \\
\hline $\begin{array}{l}\text { Workers per } \\
\text { thousand }\end{array}$ & $\begin{array}{c}0.33 \\
(0.93)\end{array}$ & $\begin{array}{c}4.43 * * * \\
(0.56)\end{array}$ & $\begin{array}{c}3.73 * * * \\
(0.73)\end{array}$ & $\begin{array}{l}6.12 * * \\
(3.09)\end{array}$ & $\begin{array}{l}1.41 * * \\
(0.55)\end{array}$ & $\begin{array}{l}3.38 * * \\
(1.36)\end{array}$ & $\begin{array}{l}2.31 \\
(1.86)\end{array}$ & $\begin{array}{l}1.34 \\
(0.95)\end{array}$ & $\begin{array}{l}1.06 \\
(1.10)\end{array}$ & $\begin{array}{l}11.94 \\
(8.32)\end{array}$ & $\begin{array}{c}20.68 * * \\
(10.50)\end{array}$ \\
\hline $\begin{array}{l}\text { (Workers per } \\
\text { thousand) }\end{array}$ & $\begin{array}{l}-0.07 \\
(0.15)\end{array}$ & $\begin{array}{c}-1.25 * * * \\
(0.24)\end{array}$ & $\begin{array}{c}-0.99 * * \\
(0.31)\end{array}$ & $\begin{array}{c}-1.87 * * \\
(0.91)\end{array}$ & $\begin{array}{c}-0.07 * * \\
(0.03)\end{array}$ & $\begin{array}{l}-0.67 \\
(0.44)\end{array}$ & $\begin{array}{l}-0.53 \\
(0.50)\end{array}$ & $\begin{array}{l}-0.06 \\
(0.09)\end{array}$ & $\begin{array}{l}-0.05 \\
(0.09)\end{array}$ & $\begin{array}{l}-1.51 \\
(2.76)\end{array}$ & $\begin{array}{l}-36.39 \\
(30.39)\end{array}$ \\
\hline $\begin{array}{l}\text { Time varying } \\
\text { hazard }\end{array}$ & Yes & No & Yes & No & Yes & No & Yes & No & Yes & No & Yes \\
\hline $\begin{array}{l}\text { Log- } \\
\text { likelihood }\end{array}$ & -50.59 & -89.09 & -64.73 & -89.44 & -77.07 & -23.11 & -21.22 & -23.35 & -21.33 & -83.03 & -67.89 \\
\hline $\mathrm{N}$ & 312 & 268 & 268 & 162 & 162 & 308 & 308 & 57 & 57 & 197 & 197 \\
\hline
\end{tabular}


Table 5: Pooled hazard model estimates of the factors influencing the timing of licensing regulation, $1880-1930$

Dependent Variable:

Licensing statute enacted

$(\mathrm{Yes}=1)$

Constant

$-4.67 * * *$

Urbanization

$(0.31)$

$1.52 * * *$

$(0.28)$

Workers per thousand

$1.32 * * *$

(Workers per thousand) $^{2}$

$(0.14)$

$-0.08 * * *$

$(0.02)$

Occupation fixed effects

(Omitted category: Barbers)

Architects

$1.86 * * *$

$(0.34)$

$1.01 * * *$

Attorneys

$(0.39)$

Beauticians

0.10

(0.36)

Dentists

$2.92 * * *$

$(0.32)$

Engineers

0.11

$(0.32)$

Nurses

$1.51 * * *$

$(0.30)$

Physicians

$1.31 * * *$

$(0.29)$

Plumbers

$-2.08 * * *$

$(0.55)$

Teachers

$-1.52 * * *$

$(0.52)$

Veterinarians

$2.76^{* * *}$

$(0.33)$

Log-likelihood

$-785.49$

$\mathrm{N}$

2462

Notes: The coefficient estimates show the change in the log-odds of adopting licensing legislation for a given occupation resulting from a one-unit change in the variable Heteroskedasticity-robust standard errors are in parentheses. Statistical significance at the 10,5 and 1 percent levels is denoted by $*{ }^{* *}$, and $* * *$ respectively. 
Table 6: Effects of occupational licensing regulation on the number of workers per 1,000 persons for eleven different occupations, 1880-1930

A. Ordinary Least Squares Estimates

\begin{tabular}{|c|c|c|c|c|c|c|c|c|c|c|c|}
\hline & Architects & Attorneys & Barbers & Beauticians & Dentists & Engineers & Nurses & Physicians & Plumbers & Teachers & Vets \\
\hline Constant & $\begin{array}{c}-0.09 * * * \\
(0.03)\end{array}$ & $\begin{array}{c}1.72 * * * \\
(0.24)\end{array}$ & $\begin{array}{c}0.31 \\
(0.21)\end{array}$ & $\begin{array}{l}-0.11 \\
(0.11)\end{array}$ & $\begin{array}{c}0.13 * * * \\
(0.05)\end{array}$ & $\begin{array}{c}-27.41 * * * \\
(14.73)\end{array}$ & $\begin{array}{c}-0.86^{* * *} \\
(0.29)\end{array}$ & $\begin{array}{c}21.05^{* * *} \\
(8.03)\end{array}$ & $\begin{array}{c}-36.35 * * * \\
(6.25)\end{array}$ & $\begin{array}{c}8.83 * * * \\
(1.12)\end{array}$ & $\begin{array}{c}-2.78 * * * \\
(0.94)\end{array}$ \\
\hline Urbanization & $\begin{array}{c}0.23 * * * \\
(0.08)\end{array}$ & $\begin{array}{c}-1.48 * * \\
(0.67)\end{array}$ & $\begin{array}{c}3.32 * * * \\
(0.44)\end{array}$ & $\begin{array}{c}0.20 \\
(0.16)\end{array}$ & $\begin{array}{c}0.05 \\
(0.12)\end{array}$ & $\begin{array}{c}1.00 \\
(1.00)\end{array}$ & $\begin{array}{c}4.19 * * * \\
(0.72)\end{array}$ & $\begin{array}{c}0.49 \\
(0.96)\end{array}$ & $\begin{array}{c}2.02 * * * \\
(0.51)\end{array}$ & $\begin{array}{l}-3.72 \\
(2.36)\end{array}$ & $\begin{array}{c}0.14 \\
(0.86)\end{array}$ \\
\hline $\begin{array}{l}\text { Per capita } \\
\text { income }\end{array}$ & $\begin{array}{c}0.00006 * * \\
(0.00002)\end{array}$ & $\begin{array}{c}0.0002 \\
(0.0002)\end{array}$ & $\begin{array}{c}0.004 * * \\
(0.002)\end{array}$ & $\begin{array}{c}0.0001 \\
(0.00007)\end{array}$ & $\begin{array}{c}0.0005 \\
(0.0003)\end{array}$ & $\begin{array}{c}0.0004 \\
(0.0004)\end{array}$ & $\begin{array}{c}0.0001 \\
(0.0002)\end{array}$ & $\begin{array}{l}-0.0002 \\
(0.0002)\end{array}$ & $\begin{array}{c}0.0001 \\
(0.0002)\end{array}$ & $\begin{array}{c}-0.003 * * * \\
(0.0007)\end{array}$ & $\begin{array}{c}-0.00009 * * \\
(0.00004)\end{array}$ \\
\hline Regulation & $\begin{array}{c}0.0009 \\
(0.01)\end{array}$ & $\begin{array}{c}0.06 \\
(0.10)\end{array}$ & $\begin{array}{l}-0.06 \\
(0.06)\end{array}$ & $\begin{array}{c}0.16^{* *} \\
(0.07)\end{array}$ & $\begin{array}{l}-0.002 \\
(0.05)\end{array}$ & $\begin{array}{c}0.10 \\
(0.14)\end{array}$ & $\begin{array}{c}0.14 \\
(0.12)\end{array}$ & $\begin{array}{l}-0.30 \\
(0.44)\end{array}$ & $\begin{array}{c}0.13 \\
(0.13)\end{array}$ & $\begin{array}{c}0.79 * * * \\
(0.30)\end{array}$ & $\begin{array}{l}0.02 * * \\
(0.008)\end{array}$ \\
\hline Adjusted-R ${ }^{2}$ & 0.77 & 0.64 & 0.84 & 0.84 & 0.68 & 0.72 & 0.46 & 0.31 & 0.84 & 0.92 & 0.69 \\
\hline $\mathrm{N}$ & 275 & 163 & 271 & 283 & 283 & 283 & 284 & 283 & 271 & 132 & 236 \\
\hline
\end{tabular}

B. Two Stage Least Squares Estimates

\begin{tabular}{|c|c|c|c|c|c|c|c|c|c|c|c|}
\hline & Architects & Attorneys & Barbers & Beauticians & Dentists & Engineers & Nurses & Physicians & Plumbers & Teachers & Vets \\
\hline Constant & $\begin{array}{c}-0.09 * * * \\
(0.03)\end{array}$ & $\begin{array}{c}1.71 * * * \\
(0.24)\end{array}$ & $\begin{array}{c}0.50 * * \\
(0.24)\end{array}$ & $\begin{array}{l}-0.13 \\
(0.12)\end{array}$ & $\begin{array}{c}-14.5 * * \\
(5.52)\end{array}$ & $\begin{array}{c}0.74 \\
(0.60)\end{array}$ & $\begin{array}{c}-69.73 * * \\
(33.03)\end{array}$ & $\begin{array}{c}21.79 * * \\
10.36)\end{array}$ & $\begin{array}{c}-37.67 * * * \\
(6.23)\end{array}$ & $\begin{array}{c}8.86 * * * \\
(1.56)\end{array}$ & $\begin{array}{c}0.10 * * * \\
(0.04)\end{array}$ \\
\hline Urbanization & $\begin{array}{l}0.26^{*} \\
(0.15)\end{array}$ & $\begin{array}{c}-1.97 * * * \\
(0.58)\end{array}$ & $\begin{array}{c}2.89 * * * \\
(0.53)\end{array}$ & $\begin{array}{l}-0.02 \\
(0.26)\end{array}$ & $\begin{array}{c}0.19 \\
(0.18)\end{array}$ & $\begin{array}{c}1.12 \\
(1.38)\end{array}$ & $\begin{array}{l}1.53 * * \\
(0.64)\end{array}$ & $\begin{array}{c}0.46 \\
(1.36)\end{array}$ & $\begin{array}{c}2.03 * * * \\
(0.51)\end{array}$ & $\begin{array}{l}-2.21 \\
(6.83)\end{array}$ & $\begin{array}{c}0.06 \\
(0.10)\end{array}$ \\
\hline $\begin{array}{l}\text { Per capita } \\
\text { income }\end{array}$ & $\begin{array}{c}0.00005 \\
(0.00004)\end{array}$ & $\begin{array}{l}0.00008 \\
(0.0002)\end{array}$ & $\begin{array}{c}0.0004 * * \\
(0.0001)\end{array}$ & $\begin{array}{l}0.0002 * * \\
(0.00001)\end{array}$ & $\begin{array}{l}-0.00006 \\
(0.00008)\end{array}$ & $\begin{array}{l}0.0006^{*} \\
(0.0003)\end{array}$ & $\begin{array}{l}-0.0004 * \\
(0.0002)\end{array}$ & $\begin{array}{l}-0.0002 \\
(0.0003)\end{array}$ & $\begin{array}{c}0.0002 \\
(0.0002)\end{array}$ & $\begin{array}{c}-0.004 * * * \\
(0.001)\end{array}$ & $\begin{array}{l}-0.00005 \\
(0.00004)\end{array}$ \\
\hline Regulation & $\begin{array}{l}-0.02 \\
(0.07)\end{array}$ & $\begin{array}{c}0.49 \\
(0.33)\end{array}$ & $\begin{array}{c}0.20 \\
(0.16)\end{array}$ & $\begin{array}{c}0.78 * * \\
(0.25)\end{array}$ & $\begin{array}{l}-0.16 \\
(0.15)\end{array}$ & $\begin{array}{l}1.27 \\
(0.90)\end{array}$ & $\begin{array}{l}-0.37 \\
(0.84)\end{array}$ & $\begin{array}{l}-0.25 \\
(1.29)\end{array}$ & $\begin{array}{l}-0.49 \\
(0.83)\end{array}$ & $\begin{array}{l}-0.73 \\
(6.66)\end{array}$ & $\begin{array}{c}0.06 \\
(0.18)\end{array}$ \\
\hline $\begin{array}{l}\text { Adjusted- } \mathrm{R}^{2} \\
\mathrm{~N}\end{array}$ & $\begin{array}{l}0.76 \\
275\end{array}$ & $\begin{array}{l}0.60 \\
163\end{array}$ & $\begin{array}{l}0.82 \\
271\end{array}$ & $\begin{array}{l}0.67 \\
283\end{array}$ & $\begin{array}{l}0.62 \\
283\end{array}$ & $\begin{array}{l}0.59 \\
283\end{array}$ & $\begin{array}{l}0.57 \\
284\end{array}$ & $\begin{array}{l}0.30 \\
284\end{array}$ & $\begin{array}{l}0.83 \\
271\end{array}$ & $\begin{array}{l}0.88 \\
132\end{array}$ & $\begin{array}{l}0.73 \\
236\end{array}$ \\
\hline
\end{tabular}

Notes: State-fixed effects were included. Heteroskedasticity robust standard errors are in parentheses. Statistical significance at the 10,5 and 1 percent levels is denoted by $* * *$, and $* * *$ respectively. 
Table 7: Effects of occupational licensing regulation on the growth rate of workers in eleven different occupations, 1880-1930 A. Ordinary Least Squares Estimates

\begin{tabular}{|c|c|c|c|c|c|c|c|c|c|c|c|}
\hline & Architect & Attorney & Barber & Beautician & Dentist & Engineer & Nurse & Physician & Plumber & Teacher & Vet \\
\hline Constant & $\begin{array}{l}-0.47^{*} \\
(0.29)\end{array}$ & $\begin{array}{l}-0.30^{*} \\
(0.19)\end{array}$ & $\begin{array}{l}-0.34 \\
(0.30)\end{array}$ & $\begin{array}{l}-13.29 \\
(8.91)\end{array}$ & $\begin{array}{c}0.35 * * * \\
(0.13)\end{array}$ & $\begin{array}{l}-0.17 \\
(0.17)\end{array}$ & $\begin{array}{l}0.50^{*} \\
(0.25)\end{array}$ & $\begin{array}{c}0.06 \\
(0.14)\end{array}$ & $\begin{array}{l}-0.15 \\
(0.26)\end{array}$ & $\begin{array}{c}0.60 * * * \\
(0.14)\end{array}$ & $\begin{array}{l}-0.04 \\
(0.30)\end{array}$ \\
\hline Population growth & $\begin{array}{c}2.02 * * * \\
(0.33)\end{array}$ & $\begin{array}{c}1.27 * * * \\
(0.15)\end{array}$ & $\begin{array}{c}1.11 * * * \\
(0.18)\end{array}$ & $\begin{array}{c}1.33 * * * \\
(0.42)\end{array}$ & $\begin{array}{c}0.99 * * * \\
(0.10)\end{array}$ & $\begin{array}{c}1.43 * * * \\
(0.25)\end{array}$ & $\begin{array}{l}0.66^{*} \\
(0.39)\end{array}$ & $\begin{array}{c}0.97 * * * \\
(0.09)\end{array}$ & $\begin{array}{c}1.80 * * * \\
(0.24)\end{array}$ & $\begin{array}{c}1.07 * * * \\
(0.14)\end{array}$ & $\begin{array}{c}1.00 * * * \\
(0.22)\end{array}$ \\
\hline Regulation & $\begin{array}{c}-0.26 * * * \\
(0.08)\end{array}$ & $\begin{array}{c}0.05 \\
(0.13)\end{array}$ & $\begin{array}{l}-0.04 \\
(0.12)\end{array}$ & $\begin{array}{c}0.64 * * * \\
(0.18)\end{array}$ & $\begin{array}{l}-0.14 \\
(0.09)\end{array}$ & $\begin{array}{l}-0.08 \\
(0.10)\end{array}$ & $\begin{array}{c}0.01 \\
(0.10)\end{array}$ & $\begin{array}{l}-0.18 \\
(0.13)\end{array}$ & $\begin{array}{l}-0.009 \\
(0.12)\end{array}$ & $\begin{array}{c}0.02 \\
(0.04)\end{array}$ & $\begin{array}{l}-0.16^{*} \\
(0.09)\end{array}$ \\
\hline Adjusted- $\mathrm{R}^{2}$ & 0.39 & 0.28 & 0.16 & 0.06 & 0.37 & 0.05 & 0.18 & 0.40 & 0.64 & 0.08 & 0.54 \\
\hline $\mathrm{N}$ & 262 & 162 & 270 & 254 & 274 & 274 & 210 & 282 & 265 & 132 & 224 \\
\hline
\end{tabular}

B. Two Stage Least Squares Estimates

\begin{tabular}{|c|c|c|c|c|c|c|c|c|c|c|c|}
\hline & Architect & Attorney & Barber & Beautician & Dentist & Engineer & Nurse & Physician & Plumber & Teacher & Vet \\
\hline Constant & $\begin{array}{c}-0.45 \\
(0.29)\end{array}$ & $\begin{array}{c}-0.16 \\
(0.28)\end{array}$ & $\begin{array}{c}-0.16 \\
(0.23)\end{array}$ & $\begin{array}{c}1.20 * * * \\
(0.44)\end{array}$ & $\begin{array}{c}0.47 * * * \\
(0.15)\end{array}$ & $\begin{array}{l}-0.10 \\
(0.19)\end{array}$ & $\begin{array}{c}0.73 \\
(0.64)\end{array}$ & $\begin{array}{c}0.54 * * * \\
(0.25)\end{array}$ & $\begin{array}{l}13.35 \\
(8.75)\end{array}$ & $\begin{array}{c}0.40 * * \\
(0.15)\end{array}$ & $\begin{array}{c}0.13 \\
(0.28)\end{array}$ \\
\hline Population growth & $\begin{array}{c}1.95 * * * \\
(0.33)\end{array}$ & $\begin{array}{c}1.20 * * * \\
(0.19)\end{array}$ & $\begin{array}{c}1.22 * * * \\
(0.20)\end{array}$ & $\begin{array}{c}0.94 * * \\
(0.37)\end{array}$ & $\begin{array}{c}0.91 * * * \\
(0.12)\end{array}$ & $\begin{array}{c}1.36 * * * \\
(0.27)\end{array}$ & $\begin{array}{c}0.57 \\
(0.51)\end{array}$ & $\begin{array}{c}0.85 * * * \\
(0.14)\end{array}$ & $\begin{array}{c}1.87 * * * \\
(0.29)\end{array}$ & $\begin{array}{c}1.24 * * * \\
(0.15)\end{array}$ & $\begin{array}{c}1.20 * * * \\
(0.22)\end{array}$ \\
\hline Regulation & $\begin{array}{c}-0.40 * * * \\
(0.14)\end{array}$ & $\begin{array}{l}-0.10 \\
(0.27)\end{array}$ & $\begin{array}{l}-0.16 \\
(0.30)\end{array}$ & $\begin{array}{c}0.49 * * \\
(0.24)\end{array}$ & $\begin{array}{c}-0.41 * * * \\
(0.12)\end{array}$ & $\begin{array}{l}-0.27 \\
(0.25)\end{array}$ & $\begin{array}{l}-0.86 \\
(1.73)\end{array}$ & $\begin{array}{c}-0.63 * * * \\
(0.23)\end{array}$ & $\begin{array}{l}-0.87 \\
(1.29)\end{array}$ & $\begin{array}{l}-0.23 \\
(0.80)\end{array}$ & $\begin{array}{c}-0.68 * * * \\
(0.12)\end{array}$ \\
\hline Adjusted-R ${ }^{2}$ & 0.38 & 0.27 & 0.11 & 0.23 & 0.33 & 0.04 & 0.17 & 0.24 & 0.42 & 0.07 & 0.30 \\
\hline $\mathrm{N}$ & 262 & 262 & 270 & 254 & 274 & 274 & 210 & 282 & 282 & 132 & 224 \\
\hline
\end{tabular}

Notes: State-fixed effects were included. Heteroskedasticity robust standard errors are in parentheses. Statistical significance at the 10,5 and 1 percent levels is denoted by $* * *$, and $* * *$ respectively. 
Table 8: Effects of medical licensing requirements on the number of physicians per 1,000 persons, $1880-1930$

Physicians per 1,000 persons

Constant

Urbanization

Income per capita

1. Initial law

2. State board

3. Licensing exam

4. College

requirement

5. Four year

requirement

6. Internship

requirement

7. Science

requirement

Early requirements

(1 and 2)

Later requirements

$(3,4,5,6,7)$

Composite licensing index

0.01

(0.07)

0.05

(0.05)

0.02

(0.05)

$-0.28 * * *$

(0.04)

$-0.09 * *$

(0.04)

0.005

(0.06)

$-0.13$

(0.11)

\section{(1)}

\section{(2)}

$1.56 * * *$

(0.16)

0.003

(0.06)

$-0.0002 *$

(0.0001)

$-0.01$

(0.07)

$-0.0001 * * *$

(0.00001)
(3)

$1.85 * * *$

(0.15)

$-0.03$

(0.10)

$-0.0003^{* * *}$

(0.0001)

$$
\begin{gathered}
0.08^{*} \\
(0.04) \\
-0.12 * * * \\
(0.02)
\end{gathered}
$$

\begin{tabular}{lccc} 
Adjusted-R & \\
$\mathrm{N}$ & 0.70 & 0.68 & 0.64 \\
\hline
\end{tabular}

Notes: State fixed effects were included. Heteroskedasticity-robust standard errors are reported in parentheses. 
Table 9: Effects of medical licensing regulation on physician incomes, 1929-32

\begin{tabular}{|c|c|c|c|c|}
\hline & $\begin{array}{c}(1) \\
\text { Dependent Variable: } \\
\text { Log(Average Gross Income })\end{array}$ & $\begin{array}{c}(2) \\
\text { Dependent Variable: } \\
\text { Log(Average Net Income) }\end{array}$ & $\begin{array}{c}(3) \\
\text { Dependent Variable: } \\
\text { Ratio of Gross Physician to Gross } \\
\text { Dentist Income }\end{array}$ & $\begin{array}{l}\text { (4) } \\
\text { Dependent Variable: } \\
\text { Ratio of Net Physician } \\
\text { to Net Dentist Income }\end{array}$ \\
\hline Constant & $\begin{array}{c}9.03 * * * \\
(0.10)\end{array}$ & $\begin{array}{c}8.45^{* * *} \\
(0.09)\end{array}$ & $\begin{array}{c}0.93^{* * *} * \\
(0.07)\end{array}$ & $\begin{array}{c}1.02 * * * \\
(0.08)\end{array}$ \\
\hline Income per capita & $\begin{array}{c}0.0001 \\
(0.0001)\end{array}$ & $\begin{array}{c}0.0003 * * * \\
(0.0001)\end{array}$ & & \\
\hline Urbanization & $\begin{array}{c}0.82 * * * \\
(0.24)\end{array}$ & $\begin{array}{l}0.46^{* *} \\
(0.22)\end{array}$ & & \\
\hline Licensing index & $\begin{array}{c}0.03 \\
(0.04)\end{array}$ & $\begin{array}{l}0.003 \\
(0.04)\end{array}$ & $\begin{array}{c}0.05 \\
(0.06)\end{array}$ & $\begin{array}{c}0.05 \\
(0.08)\end{array}$ \\
\hline Adjusted- $\mathrm{R}^{2}$ & 0.22 & 0.23 & 0.92 & 0.82 \\
\hline $\mathrm{N}$ & 192 & 192 & 192 & 192 \\
\hline
\end{tabular}

Notes: State fixed-effects were included but are not reported. Heteroskedasticity-robust standard errors are in parentheses. Statistical significance at the 10, 5 and 1 percent levels is denoted by $*, * *$, and $* * *$ respectively. 
Table 10: Effects of medical licensing requirements on state level mortality rates due to different causes, 1900-1930

\begin{tabular}{|c|c|c|c|c|c|c|}
\hline \multicolumn{7}{|c|}{ Mortality rate per 100,000 persons from 1900 to 1930 (unless otherwise specified) } \\
\hline & $\begin{array}{c}\text { (1) } \\
\text { Overall mortality } \\
\text { rate }\end{array}$ & $\begin{array}{c}(2) \\
\text { Cancer mortality } \\
\text { rate }\end{array}$ & $\begin{array}{c}\text { (3) } \\
\text { Diabetes mortality } \\
\text { rate }^{\mathrm{a}}\end{array}$ & $\begin{array}{c}\text { (4) } \\
\text { Infant mortality } \\
\text { rate }^{b}\end{array}$ & $\begin{array}{c}\text { (5) } \\
\text { Maternal mortality } \\
\text { rate }^{\mathrm{c}}\end{array}$ & $\begin{array}{c}\text { (6) } \\
\text { Appendicitis } \\
\text { mortality rate }^{\mathrm{d}}\end{array}$ \\
\hline Constant & $\begin{array}{c}882.78 \\
(750.49)\end{array}$ & $\begin{array}{c}10.15 \\
(16.23)\end{array}$ & $\begin{array}{l}11.07 * \\
(7.64)\end{array}$ & $\begin{array}{c}187.47 * * * \\
(26.92)\end{array}$ & $\begin{array}{c}12.80 * * * \\
(6.20)\end{array}$ & $\begin{array}{c}20.02 * * \\
(7.04)\end{array}$ \\
\hline Urbanization & $\begin{array}{c}18.17 \\
(128.14)\end{array}$ & $\begin{array}{l}-0.18 \\
(4.45)\end{array}$ & $\begin{array}{l}-0.49 \\
(0.67)\end{array}$ & $\begin{array}{l}9.01 * * \\
(4.22)\end{array}$ & $\begin{array}{c}0.10 \\
(0.18)\end{array}$ & $\begin{array}{c}0.55 \\
(2.45)\end{array}$ \\
\hline Income per capita & $\begin{array}{c}-0.53 * * \\
(0.21)\end{array}$ & $\begin{array}{c}0.003 \\
(0.007)\end{array}$ & $\begin{array}{l}0.009 * \\
(0.002)\end{array}$ & $\begin{array}{c}-0.09 * * * \\
(0.01)\end{array}$ & $\begin{array}{l}0.0004 \\
(0.001)\end{array}$ & $\begin{array}{c}0.010 * * \\
(0.003)\end{array}$ \\
\hline $\begin{array}{l}\text { Physicians per } \\
1,000 \text { persons }\end{array}$ & $\begin{array}{c}339.15 \\
(350.13)\end{array}$ & $\begin{array}{l}-9.72 \\
(8.83)\end{array}$ & $\begin{array}{c}-10.58 * * \\
(4.29)\end{array}$ & $\begin{array}{l}-18.38 \\
(12.26)\end{array}$ & $\begin{array}{l}-0.51 \\
(2.30)\end{array}$ & $\begin{array}{c}-10.63 * * \\
(4.79)\end{array}$ \\
\hline $\begin{array}{l}\text { Composite } \\
\text { licensing index }\end{array}$ & $\begin{array}{c}140.47 \\
(209.35)\end{array}$ & $\begin{array}{c}0.24 \\
(1.37)\end{array}$ & $\begin{array}{l}-0.38 \\
(0.71)\end{array}$ & $\begin{array}{c}-7.78 * * \\
(3.52)\end{array}$ & $\begin{array}{c}-1.04 * * * \\
(0.35)\end{array}$ & $\begin{array}{c}-1.82 * * \\
(0.88)\end{array}$ \\
\hline $\begin{array}{l}\text { Adjusted- } \mathrm{R}^{2} \\
\mathrm{~N}\end{array}$ & $\begin{array}{c}0.25 \\
111\end{array}$ & $\begin{array}{l}0.9 \\
108\end{array}$ & $\begin{array}{c}0.80 \\
80\end{array}$ & $\begin{array}{c}0.86 \\
65\end{array}$ & $\begin{array}{c}0.88 \\
69\end{array}$ & $\begin{array}{c}0.67 \\
100\end{array}$ \\
\hline
\end{tabular}

Notes: State fixed effects were included in each regression. Heteroskedasticity robust standard errors are in parentheses.

${ }^{a}$ Since insulin treatment was only developed in 1922, we restricted our sample to diabetes mortality rates in 1920 and 1930 for this regression.

${ }^{\mathrm{b}}$ The infant mortality rate is expressed as the number of deaths of children less than 1 year old per 1,000 children 1 year of age or less. Estimates of the number of children 1 year of age or less were not available for every state in the registration area; hence, the sample size is smaller for this regression.

${ }^{c}$ The maternal mortality rate is expressed as the number of deaths due to childbirth per 1,000 live births. This data were only available for selected states in 1920 and 1930; hence the sample size is smaller for this regression

${ }^{\mathrm{d}}$ Data on deaths due to appendicitis were only available for 1910, 1920, and 1930; hence, the sample size is smaller for this regression. 
Table 11: Effects of medical licensing requirements on the number of state-level appeals court malpractice cases per 1 million persons for each decade, 1880-1930

Malpractice cases at state appeals courts per 1 million persons for each decade

\begin{tabular}{|c|c|c|c|c|}
\hline & (1) & (2) & (3) & (4) \\
\hline Constant & $\begin{array}{c}1.81 \\
(3.57)\end{array}$ & $\begin{array}{l}1.43 \\
(3.87)\end{array}$ & $\begin{array}{l}1.33 \\
(3.73)\end{array}$ & $\begin{array}{c}0.96 \\
(3.78)\end{array}$ \\
\hline Urbanization & $\begin{array}{l}-0.12 \\
(1.01)\end{array}$ & $\begin{array}{l}-0.19 \\
(1.04)\end{array}$ & $\begin{array}{l}-0.05 \\
(1.04)\end{array}$ & $\begin{array}{l}0.003 \\
(1.04)\end{array}$ \\
\hline $\begin{array}{l}\text { Physicians per } 1,000 \\
\text { persons }\end{array}$ & $\begin{array}{l}-0.24 \\
(0.87)\end{array}$ & $\begin{array}{l}-0.15 \\
(0.94)\end{array}$ & $\begin{array}{l}-0.13 \\
(0.88)\end{array}$ & $\begin{array}{l}-0.44 \\
(0.85)\end{array}$ \\
\hline Income per capita & $\begin{array}{l}0.0005 \\
(0.001)\end{array}$ & $\begin{array}{l}0.0008 \\
(0.002)\end{array}$ & $\begin{array}{l}0.0008 \\
(0.002)\end{array}$ & $\begin{array}{c}0.001 \\
(0.002)\end{array}$ \\
\hline 1. Initial law & $\begin{array}{c}0.84 \\
(0.84)\end{array}$ & & & \\
\hline 2. State board & $\begin{array}{c}0.69 \\
(0.65)\end{array}$ & & & \\
\hline 3. Licensing exam & $\begin{array}{l}1.23 * * \\
(0.61)\end{array}$ & $\begin{array}{l}1.18^{*} \\
(0.63)\end{array}$ & & \\
\hline $\begin{array}{l}\text { 4. College } \\
\text { requirement }\end{array}$ & $\begin{array}{c}0.94 \\
(0.84)\end{array}$ & & & \\
\hline $\begin{array}{l}\text { 5. Four year } \\
\text { requirement }\end{array}$ & $\begin{array}{l}1.93 * * \\
(0.78)\end{array}$ & $\begin{array}{c}1.83 * * \\
(0.76)\end{array}$ & & \\
\hline $\begin{array}{l}\text { 6. Internship } \\
\text { requirement } \\
\text { 7. Basic science } \\
\text { requirement }\end{array}$ & $\begin{array}{c}1.13 \\
(1.71) \\
2.65 \\
(2.22)\end{array}$ & & & \\
\hline $\begin{array}{l}\text { Early requirements } \\
(1 \text { and } 2)\end{array}$ & & $\begin{array}{c}0.73 \\
(0.48)\end{array}$ & $\begin{array}{c}0.70 \\
(0.48)\end{array}$ & \\
\hline $\begin{array}{l}\text { College, internship } \\
\text { and science }(4,6,7)\end{array}$ & & $\begin{array}{l}1.20^{*} \\
(0.76)\end{array}$ & & \\
\hline $\begin{array}{l}\text { Later requirements } \\
(3,4,5,6,7)\end{array}$ & & & $\begin{array}{c}1.36^{* * * *} \\
(0.34)\end{array}$ & \\
\hline $\begin{array}{l}\text { Composite licensing } \\
\text { index }\end{array}$ & & & & $\begin{array}{c}1.09 * * * \\
(0.23)\end{array}$ \\
\hline Adjusted-R ${ }^{2}$ & 0.38 & 0.39 & 0.39 & 0.39 \\
\hline D-W statistic & 1.96 & 1.95 & 1.95 & 1.95 \\
\hline $\mathrm{N}$ & 282 & 282 & 282 & 282 \\
\hline
\end{tabular}

Notes: State fixed effects and a time trend were included. Heteroskedasticity robust standard errors are displayed in parentheses. Statistical significance at the 10,5 and 1 percent levels is denoted by *,**, and $* * *$ respectively. 